\title{
Optical-microphysical properties of Saharan dust aerosols and composition relationship using a multi-wavelength Raman lidar, in situ sensors and modelling: a case study analysis
}

\author{
A. Papayannis ${ }^{1}$, R. E. Mamouri ${ }^{1}$, V. Amiridis ${ }^{2}$, E. Remoundaki ${ }^{3}$, G. Tsaknakis ${ }^{1}$, P. Kokkalis ${ }^{1}$, I. Veselovskii ${ }^{4}$, \\ A. Kolgotin ${ }^{4}$, A. Nenes ${ }^{5,6}$, and C. Fountoukis ${ }^{6}$ \\ ${ }^{1}$ National Technical University of Athens, Laser Remote Sensing Laboratory, Zografou, Greece \\ ${ }^{2}$ National Observatory of Athens, Institute for Space Applications and Remote Sensing, Athens, Greece \\ ${ }^{3}$ National Technical University of Athens, School of Mining and Metallurgical Engineering, Zografou, Greece \\ ${ }^{4}$ Physics Instrumentation Center for General Physics, Troitsk, Moscow, Russia \\ ${ }^{5}$ Schools of Earth \& Atmospheric Sciences and Chemical \& Biomolecular Engineering, Georgia Institute of Technology, \\ Atlanta, GA, USA \\ ${ }^{6}$ Institute of Chemical Engineering and High Temperature Chemical Processes, Foundation for Research and Technology \\ Hellas (FORTH), Patras, Greece
}

Correspondence to: A. Papayannis (apdlidar@central.ntua.gr)

Received: 11 July 2011 - Published in Atmos. Chem. Phys. Discuss.: 12 September 2011

Revised: 29 March 2012 - Accepted: 6 April 2012 - Published: 7 May 2012

\begin{abstract}
A strong Saharan dust event that occurred over the city of Athens, Greece $\left(37.9^{\circ} \mathrm{N}, 23.6^{\circ} \mathrm{E}\right)$ between 27 March and 3 April 2009 was followed by a synergy of three instruments: a 6-wavelength Raman lidar, a CIMEL sun-sky radiometer and the MODIS sensor. The BSC-DREAM model was used to forecast the dust event and to simulate the vertical profiles of the aerosol concentration. Due to mixture of dust particles with low clouds during most of the reported period, the dust event could be followed by the lidar only during the cloud-free day of 2 April 2009. The lidar data obtained were used to retrieve the vertical profile of the optical (extinction and backscatter coefficients) properties of aerosols in the troposphere. The aerosol optical depth (AOD) values derived from the CIMEL ranged from $0.33-0.91(355 \mathrm{~nm})$ to 0.18 $0.60(532 \mathrm{~nm})$, while the lidar ratio (LR) values retrieved from the Raman lidar ranged within 75-100 sr (355 nm) and 45-75 sr $(532 \mathrm{~nm})$. Inside a selected dust layer region, between 1.8 and $3.5 \mathrm{~km}$ height, mean LR values were $83 \pm 7$ and $54 \pm 7 \mathrm{sr}$, at 355 and $532 \mathrm{~nm}$, respectively, while the Ångström-backscatter-related (ABR $355 / 532)$ and Ångströmextinction-related $\left(\mathrm{AER}_{355 / 532}\right)$ were found larger than 1 $(1.17 \pm 0.08$ and $1.11 \pm 0.02$, respectively), indicating mixing of dust with other particles. Additionally, a retrieval tech-
\end{abstract}

nique representing dust as a mixture of spheres and spheroids was used to derive the mean aerosol microphysical properties (mean and effective radius, number, surface and volume density, and mean refractive index) inside the selected atmospheric layers. Thus, the mean value of the retrieved refractive index was found to be $1.49( \pm 0.10)+0.007( \pm 0.007) \mathrm{i}$, and that of the effective radiuses was $0.30 \pm 0.18 \mu \mathrm{m}$. The final data set of the aerosol optical and microphysical properties along with the water vapor profiles obtained by Raman lidar were incorporated into the ISORROPIA II model to provide a possible aerosol composition consistent with the retrieved refractive index values. Thus, the inferred chemical properties showed $12-40 \%$ of dust content, sulfate composition of 16-60\%, and organic carbon content of 15-64\%, indicating a possible mixing of dust with haze and smoke. $\mathrm{PM}_{10}$ concentrations levels, $\mathrm{PM}_{10}$ composition results and SEM-EDX (Scanning Electron Microscope-Energy Dispersive X-ray) analysis results on sizes and mineralogy of particles from samples during the Saharan dust transport event were used to evaluate the retrieval. 


\section{Introduction}

Atmospheric aerosols have a large impact on the planetary radiation budget, and are thought to exert a net cooling effect on climate (Andreae, 1995; Ramanathan et al., 2001; Heinold et al., 2007; Levin and Cotton, 2009; Ramanathan and Feng, 2009; Lohmann et al., 2010). The cooling effect associated with anthropogenic aerosol is thought to partially mitigate greenhouse gas warming, but estimates of the radiative forcing pattern still remain complex and highly uncertain, owing to the large spatio-temporal variability of aerosol dust and their complex interaction with atmospheric constituents, radiation and clouds (Satheesh et al., 2005; Forster et al., 2007; Min et al., 2009). As mineral dust accounts for about $75 \%$ of the global aerosol mass load and $25 \%$ of the global aerosol optical depth (Kinne et al., 2006) and is a key player in Earth's climate (Mahowald et al., 2006; Balkanski et al., 2007, Bierwirth et al., 2009; Otto et al., 2009; Müller et al., 2011) affecting precipitation (Yoshioka et al., 2007), it is very important to quantify its effects on Earth's radiative forcing, both in the short-wave $(0.3-4 \mu \mathrm{m})$ and longwave $(4-50 \mu \mathrm{m})$ spectral regions (Sokolik and Toon, 1999; Sokolik et al., 2001). For the assessment of the radiative effects of dust, it is imperative to obtain accurate data on the vertical profiling of its optical and microphysical properties, as well as its chemical composition around the globe. Although specific dust experiments (e.g. SAMUM 1 and 2) (Ansmann et al., 2011 and references their in) focused also on the estimation of the radiative effects of dust, their results had a rather regional (Saharan region) and a limited temporal coverage; therefore, systematic vertical profiles of aerosol optical-microphysical and chemical data around the globe are still missing, and open questions about the aerosol role on climate yet exist.

The gap concerning the vertical profiling of the aerosol properties can be filled by synergy of systematic lidar (ground-based, airborne and space-borne measurements to derive the optical-microphysical properties) and of in situ measurements (to derive the optical-microphysical-chemical properties) (e.g. Kandler et al., 2009; Weinzierl et al., 2009; Lieke et al., 2011), which are able to provide much of the information required to constrain models and reduce uncertainties associated with radiative forcing estimate. Although the in situ airborne measurements are information-rich, they remain extremely expensive and limited in both time and space.

To fulfill the gap of the vertical profiling of the aerosol optical-microphysical properties over the globe, two major aerosol monitoring schemes currently exist: (a) groundbased lidar networks: the European Aerosol Research Lidar Network (EARLINET; http://www.earlinet.org), the Asian Dust Network, (AD-Net; www-lidar.nies.go.jp/AsiaNet) and the Micropulse Lidar Network (MPL-Net; http://mplnet. gsfc.nasa.gov), which are members of the Global Atmosphere Watch (GAW), Aerosol Lidar Observation Network (GALION) promoted by the World Meteorological Organi- zation (WMO), and (b) space-borne active remote sensing sensors (e.g. LITE and CALIOP lidars) (Berthier et al., 2006; Winker et al., 2007, 2010; Mamouri et al., 2009; Mona et al., 2009; Pappalardo et al., 2010; Liu et al., 2011). Groundbased sun-sky radiometer networks, such as the Aerosol Robotic Network (AERONET) that measures sun and sky radiances in 16 spectral channels $(340-1640 \mathrm{~nm})$ (Holben et al., 1998; Eck et al., 2005) in combination with several passive space-borne sensors (e.g. MODIS, OMI, MERIS, MISR, etc.), can provide information about the total column dust optical-microphysical properties over the globe (e.g. Santese et al., 2008; Amiridis et al., 2009a,b; Carboni et al., 2012; Kim et al., 2012; Redemann et al., 2012; Ridley et al., 2012).

The potential of the lidar technique to provide the vertical profiles of the aerosol optical-microphysical properties over the globe, with emphasis on pure desert dust or mixed dust, has been proven by the measurements performed by the above-mentioned lidar networks or by specific experimental campaigns like: Asian Pacific Regional Aerosol Characterization Experiment (ACE-ASIA), African Monsoon Multidisciplinary Analysis (AMMA), Dust and Biomass-burning Experiment (DABEX), Dust Outflow and Deposition to the Ocean (DODO), Indian Ocean Experiment (INDOEX), NASA AMMA (NAMMA), Puerto Rico Dust Experiment (PRIDE), Saharan Mineral Dust Experiment (SAMUM 1 and 2), Saharan Dust Experiment (SHADE), Unified Aerosol Experiment (UAE2), etc. (Müller et al., 1999, 2003, 2005, 2009, 2010; Ramanathan et al., 2001; Ansmann et al., 2003; Blanco et al., 2003; Feingold and Morley, 2003; Léon et al., 2003; Reid et al., 2003; Sugimoto et al., 2003; Balis et al., 2004; Kim et al., 2004; Haywood et al., 2005; Pahlow et al., 2006; Cuesta et al., 2008; Hansell et al., 2008; Heese and Wiegner, 2008; Mattis et al., 2008; Papayannis et al., 2008; Tesche et al., 2009a,b; Pappalardo et al., 2010; Ansmann et al., 2011; Chen et al., 2011; T. Müller et al., 2011; Sicard et al., 2011; Tesche et al., 2011a,b).

Our study aims to fulfill the existing gap on the vertical profiling of the aerosol dust properties, focusing on the retrieval of the vertical profiling of the optical, microphysical and composition of aged dust aerosol particles associated with a strong saharan dust event, as they interact with anthropogenic particles in the lower free troposphere over an urban site (Athens, Greece). In the following sections we first present the dust forecasting model, instrumentation and methodology used for retrieving the aerosol properties (Sect. 2). An analysis of the dust event then follows with an emphasis on the days with optimal lidar retrievals (Sect. 3). We provide final remarks and a summary of the work carried on this paper in Sect. 4. 


\section{Methodology}

\subsection{The NTUA 6-wavelength Raman lidar system}

The National Technical University of Athens (NTUA) lidar system is located on Campus in the city of Athens $\left(37.97^{\circ} \mathrm{N}\right.$, $23.79^{\circ} \mathrm{E}, 200 \mathrm{~m}$ a.s.l.), and has been continuously operating since the initiation of the EARLINET project (Bösenberg et al., 2003) in February 2000. The compact 6-wavelength NTUA Raman lidar system (Mamouri et al., 2008) is based on a pulsed Nd:YAG laser emitting simultaneously at 355, 532 and $1064 \mathrm{~nm}$. The lidar signals are detected at six wavelengths $355,387,407,532,607$ and $1064 \mathrm{~nm}$. The system has been quality-assured by performing direct intercomparisons, both at hardware (Matthias et al., 2004) and software levels (Böckmann et al., 2004; Pappalardo et al., 2004).

To obtain reliable and quantitative lidar aerosol retrievals, several techniques and methods have to be combined. The standard backscatter lidar technique is appropriate to retrieve aerosol parameters mostly for small aerosol optical depths ( $\mathrm{AOD}<0.2-0.3$ in the visible), assuming a reference height in an aerosol-free area (e.g. the upper troposphere). Under such conditions, the Klett inversion technique (Klett, 1985) is used to retrieve the vertical profile of the aerosol backscatter coefficient $\left(b_{\text {aer }}\right)$ at the respective wavelengths, during daytime. The resulting average uncertainty on the retrieval of $b_{\text {aer }}$ (including both statistical and systematic errors corresponding to a $30-60 \mathrm{~min}$ averaging time) in the troposphere is of the order of 20-30\% (Bösenberg et al., 1997). To overcome this large uncertainty, the Raman $\mathrm{N}_{2}$ lidar technique was adopted using the methodology of Ansmann et al. (1992). Since the Raman lidar signals are quite weak, the Raman technique is mostly used during nighttime, when the atmospheric background is low.

In the case of the Raman technique, the measurement of the elastic backscatter signals at 355 and $532 \mathrm{~nm}$, as well as that of the $\mathrm{N}_{2}$ inelastic-backscatter signals at 387 and $607 \mathrm{~nm}$, respectively, permits the determination of the extinction $\left(a_{\text {aer }}\right)$ and $b_{\text {aer }}$ coefficients independently of each other (Ansmann et al., 1992) and thus, of the extinction-tobackscatter ratio, the so-called lidar ratio $\left(\mathrm{LR}=a_{\text {aer }} / b_{\text {aer }}\right)$ at both wavelengths ( 355 and $532 \mathrm{~nm}$ ). The LR values depend on the chemical composition of aerosols (absorption characteristics), the size distribution and shape characteristics (Ansmann et al., 2003), while the other lidar-derived parameters, at wavelengths $\lambda_{1}$ and $\lambda_{2}$ (in nm), such as the Ångström backscatter-related $\left(\mathrm{ABR}_{\lambda_{1} / \lambda_{2}}=\frac{\ln \left[b_{\operatorname{arr}}\left(\lambda_{1}\right) / b_{\left.\operatorname{ar}\left(\lambda_{2}\right)\right]}\right]}{\ln \left[\lambda_{1} / \lambda_{2}\right]}\right)$ and the Ångström extinction-related $\left(\operatorname{AER}_{\lambda_{1} / \lambda_{2}}=\frac{\ln \left[a_{\operatorname{arr}\left(\lambda_{1}\right) / a_{\left.\operatorname{ar}\left(\lambda_{2}\right)\right]}} \ln \left[\lambda_{1} / \lambda_{2}\right]\right.}{\cos }\right)$ exponent (Ansmann et al., 2002), depend on the particle size, shape and the wavelength dependence of the absorption coefficient, respectively (Ansmann et al., 2003). The relative errors of $b_{\text {aer }}$ and $a_{\text {aer }}$, of LR, of ABR and AER are mainly due to the presence of noise on the received lidar signal. Ad- ditionally, the lidar backscatter profile must be calibrated at a reference height region with negligible aerosol scattering (i.e., with only Rayleigh scattering). This uncertainty in the calibration region in the upper aerosol-free troposphere (at 355-532-1064 nm) may lead to further errors. Finally, by assuming all errors are random, uncorrelated and assigning reasonable uncertainties at the input parameters mentioned above and the lidar overlap function, the remaining systematic uncertainties are of the order of $10-20 \%$ on $b_{\text {aer }}$, and $10-15 \%$ on $a_{\text {aer }}$ (Ansmann et al., 1992; Mattis et al., 2002). Therefore, the corresponding uncertainty on LR is of the order of 14-25\%, while on ABR and AER is if the order of $20-35 \%$ and $20-30 \%$, respectively. To reduce the relative errors on the vertical profile of $b_{\text {aer }}$ (to about $15-20 \%$ ) retrieved before the local sunset time $(\sim 19: 00$ UT) when the Klett technique is used, we applied the LR values retrieved by the Raman technique (Ansmann et al., 1992) from the nighttime period of the same day as the Saharan dust event occurred (2 April 2009).

\subsection{The CIMEL sun-sky radiometer}

The sun photometric observations reported in this paper were performed by a CIMEL sun-sky radiometer, which is part of AERONET (http://aeronet.gsfc.nasa.gov) (Holben et al., 1998). The instrument is located on the roof of the Research Center for Atmospheric Physics and Climatology of the Academy of Athens ( $37.99^{\circ} \mathrm{N}, 23.78^{\circ} \mathrm{E}$, elevation: $130 \mathrm{~m}$ ). The site is located in the city center and $10 \mathrm{~km}$ from the sea. This sunphotometric station is operated by the Institute for Space Applications and Remote Sensing (ISARS) of the National Observatory of Athens (NOA). The CIMEL data used in this study will provide information about the columnar AOD, aerosol size distribution, aerosol microphysical properties, and Ångström exponent $(\alpha)$. The inverted aerosol size distributions refer to aerosol radius ranging from $0.01 \mu \mathrm{m}$ to $15 \mu \mathrm{m}$. The expected accuracy for the AERONET inversions is of the order of $15-25 \%$ for radius greater than $0.5 \mu \mathrm{m}$ and $25-100 \%$ for radius less than $0.5 \mu \mathrm{m}$. The AERONET data products description and accuracy along with the technical specifications of the CIMEL instrument are given in detail in Holben et al. (1998, 2006) and Smirnov et al. (2000).

\subsection{The MODIS instrument}

The Moderate Resolution Imaging Spectroradiometer (MODIS) was launched in December 1999 on the polar orbiting Terra spacecraft and since February 2000 has been acquiring daily global data in 36 spectral bands from the visible to the thermal infrared (29 spectral bands with $1 \mathrm{~km}, 5$ spectral bands with $500 \mathrm{~m}$, and 2 spectral bands with $250 \mathrm{~m}$ nadir pixel dimensions). The MODIS aerosol products are only created for cloud-free regions. The columnar AOD values are retrieved by MODIS at $550 \mathrm{~nm}$ (http://modis-atmos.gsfc.nasa.gov/products.html) for both 
oceans (best) and land (corrected) (Tanré et al., 1997; Kaufman and Tanré, 1998; Levy et al., 2007; Russel et al., 2007; Remer et al., 2008; Redemann et al., 2012). The main sources of uncertainty in the retrieval of the AOD in this case are from instrument calibration errors, cloud-masking errors, incorrect assumptions on surface reflectance and aerosol-size distribution, selection (Remer et al., 2005; Levy et al., 2010). The pre-launch conditions suggested that 1 standard deviation of retrievals would fall within $\pm(0.03+0.05 \mathrm{AOD})$ over ocean and $\pm(0.05+0.15 \mathrm{AOD})$ over land. These error bounds, derived pre-launch, are referred to as the expected error (EE) (Remer et al., 2005; Levy et al., 2010; Kleidman et al., 2012).

To minimize the uncertainties on the MODIS AOD product several validation studies have been performed during pre-launch and post-launch procedures, regarding the AOD measurements using ground-based instrumentation (Chu et al., 2003; Remer et al., 2005; Misra et al., 2008; Papadimas et al., 2009; Prasad and Singh, 2009). More recently, Levy et al. (2010) performed a global evaluation of the MODIS Collection 5 (C005) dark-target aerosol products over land, showing that more than $66 \%$ (one standard deviation) of MODIS-retrieved AOD values compared to AERONET observed values within an expected error (EE) envelope of $\pm(0.05+15 \%)$, with high correlation $(R=0.9)$. According to the same authors, Terra's global AOD bias changes with time, underestimating by $\sim 0.005$, after the year 2004 . However, although validated globally, MODIS-retrieved AOD does not fall within the EE envelope in all regions of the planet (Levy et al., 2010).

In this study we used MODIS C005 data, which were recently evaluated and validated for the Greater Mediterranean Basin $\left(29.5^{\circ} \mathrm{N}-46.5^{\circ} \mathrm{N}\right.$ and $\left.10.5^{\circ} \mathrm{W}-38.5^{\circ} \mathrm{E}\right)$ against 29 AERONET stations, as described by Papadimas et al. (2009). The same study found that when comparing C005 to C004 data, the correlation coefficient increases from 0.66 to 0.76 , and the slope of the linear regression fit from 0.79 to 0.85 whereas the offset decreased from 0.12 to 0.04 , and the scatter of compared data pairs from 0.15 to 0.12 . On the other hand, they found a significant decrease of AOD values over land (by $25.8 \%$ ) for AODs $>0.2$. However, the MODIS C005 data still overestimate/underestimate the AERONET AOD values smaller/larger than 0.25 , but to a much smaller extent than C004 data. More precisely, collocated MODIS retrievals with data from our AERONET station are evaluated, and the good comparison revealed justifies the MODIS retrieval for the day under study. For that day, the scattering angle of the MODIS observation used for comparison with AERONET was $133.26^{\circ}$ and the aerosol type retrieved over land was equal to 2 .

\subsection{The BSC-DREAM dust model}

The Barcelona Supercomputing Center - Dust Regional Atmospheric Model (BSC-DREAM) (Nickovic et al., 2001) has been delivering operational dust forecasts over the North Africa-Mediterranean-Middle East and over Asia in the last years (currently at www.bsc.es/projects/earthscience/ DREAM/). The model simulates the 3-dimensional field of the dust concentration in the troposphere. The dust model takes into account all major processes of dust life cycle, such as dust production, horizontal and vertical diffusion, advection wet and dry deposition, while the chemical aging and aerosol-cloud interactions are not taken into account. The model also includes the effects of the particle size distribution on aerosol dispersion. The model numerically solves the Euler-type mass partial differential equation by integrating it spatially and temporally. The dust production is parameterized using near surface turbulence and stability as well as soil features. The dust production mechanism is based on viscous turbulent mixing close to the surface and on soil moisture content.

In BSC-DREAM, for each soil texture type, fractions of clay, small silt, large silt and sand are estimated with typical particle size radii of $0.73,6.1,18$ and $38 \mu \mathrm{m}$, respectively. For the present study, BSC-DREAM simulation is initialized with 24-hourly (at 12:00 UTC) updated NCEP (National Centers for Environmental Prediction) $0.5^{\circ} \times 0.5^{\circ}$ analysis data and the initial state of the dust concentration in the model is defined by the 24-h forecast from the previousday model run (because there are not yet satisfactory threedimensional dust concentration observations to be assimilated). The resolution is set to $0.33^{\circ} \times 0.33^{\circ}(\sim 50 \mathrm{~km})$ in the horizontal, while in the vertical the model domain extends up to $15 \mathrm{~km}$ height within 24 layers. For long-range dust transport studies, only the first two classes $(0.73$ and $6.1 \mu \mathrm{m})$ are relevant for the analysis particles since their lifetime is larger than about $12 \mathrm{~h}$.

\subsection{Derivation of the aerosol microphysical and chemical properties using models}

The measured vertical profiles of the aerosol backscatter and extinction coefficients at multiple wavelengths can be inverted to derive particle microphysical parameter profiles (Müller et al., 1999; Veselovskii et al., 2002, 2009; Osterloch et al., 2011). However, this kind of inversion is an illposed problem requiring regularization (Engl et al., 2000), therefore, "unique" (unambiguous) solutions will never be available. Furthermore, an application of this technique to dust needs to account for the particles non sphericity, given that backscattering by irregularly shaped particles is weaker than by equivalent-volume spheres (Mishchenko and Hovenier, 1995). To address this issue, Mishchenko et al. (1997) suggested approximating the dust particles with a mixture of polydisperse, randomly oriented spheroids, as they can 
mimic the aerosol optical properties. Dubovik et al. (2006) have included the spheroid model in the AERONET retrieval algorithm, while Merikallio et al. (2011) studied the applicability of spheroidal model particles for simulating the single-scattering optical properties of mineral dust aerosols. Veselovskii et al. (2010) introduced the spheroid model into the lidar retrieval of dust particles physical properties, by assuming that aerosols are a mixture of spheres and randomly oriented spheroids with a size-independent shape distribution. This assumption is applied to all particles. However, we must keep in mind that for the fine mode the optical properties of spheres and spheroids are very close and important differences occur only for the coarse mode. Besides, the output result is not very sensitive to the exact type of shape distribution (not shown), justifying the assumption of sizeindependent shape proposed. Moreover, our numerical simulations demonstrate that for $10 \%$ uncertainty of input optical data (backscatter and extinction coefficients) the dust particle volume density and the effective radius can be estimated to within $30 \%$.

The unknown shape of the aerosols remains an unresolved issue, although progress has been recently made both in the case of Saharan dust (Gasteiger et al., 2011a) and volcanic ash (Gasteiger et al., 2011b) by assuming mixtures of absorbing and non-absorbing irregularly shaped mineral dust particles and spheroids, respectively. For dust particles in SAMUM-2, Gasteiger at al. (2011b) found that irregularly shaped dust particles with typical refractive indices, in general, have higher linear depolarization ratios than corresponding spheroids, and improved the agreement with the observations. However, these models remain too complicated and time consuming for their implementation in inversion algorithm, so in our study we are using a simplified spheroidal model, which allows reasonable estimation of the dust particle parameters.

In this paper the microphysical properties of the aerosols in the lower free troposphere, inside the dust layer, were retrieved using the regularization technique (Veselovskii et al., 2002, 2004, 2010), which used as input the vertical profiles of the aerosol extinction $a_{\text {aer }}$ (at $355-532 \mathrm{~nm}$ ) and backscatter coefficients $b_{\text {aer }}$ (at 355-532-1064 nm) retrieved from the elastic (during daytime only $b_{\text {aer }}$ was retrieved by the elastic channels) and Raman (during night time $b_{\text {aer }}$ and $a_{\text {aer }}$ were retrieved, independently) backscattered lidar signals (obtained at 5 different wavelengths: 355-387-532$607-1064 \mathrm{~nm})$. The inverted aerosol microphysical properties are the effective radius $\left(r_{\text {eff }}\right)$, the total number $(N)$, the surface area $(S)$ and volume $(V)$, as well as the real and imaginary parts of the particle refractive index $\left(m_{R}\right.$ and $m_{i}$, respectively), within different layers in the lower troposphere (1.8-3.5 km height asl.). In our approach we do not consider the spectral dependence of the refractive index, or the chemical composition of the aerosol particles. Thus, the retrieved values of the refractive index are the average ones with respect to the size and spectral range considered (355-
$1064 \mathrm{~nm}$ ). Additionally, in our retrieval we consider $m_{R}$ to be in the range $1.33-1.65, m_{i}$ in the range $0-0.02$, and the aerosol particles diameters in the range between $0.15-20 \mu \mathrm{m}$. The uncertainty on the $m_{R}$ and $m_{i}$ retrieval is of the order of \pm 0.05 and $\pm 50 \%$, respectively, according to Veselovskii et al. (2010); the corresponding uncertainty of the retrieved values of the effective radius, volume and surface density is about $\pm 30 \%$. Finally, the uncertainty on the number density estimation is about $50 \%$ (Veselovskii et al., 2010).

We have of course to clarify here that the inverse problem (using lidar data to retrieve the aerosol micro-physical properties) in our formulation is underdetermined: the set of lidar measurements within a single atmospheric layer is extremely limited to 5 different profiles ( $3 b_{\text {aer }}$ and $2 a_{\text {aer }}$ ) and this is not sufficient to uniquely describe the properties of the aerosol. Therefore, we fit the observation and identify not a unique solution but a family of solutions instead. Specifically, a series of solutions is generated using different initial guesses, different aerosol assumptions and different settings of a priori constraints. Each single solution is obtained using the regularization technique. Then the individual solutions corresponding to the smallest residuals are averaged and the result of the averaging is taken as the best estimate of the aerosol properties. This approach has demonstrated possibility to provide rather adequate retrieval of aerosol properties (Veselovskii et al., 2009).

The inverted refractive index (which corresponds to in situ conditions, i.e. includes aerosol water) along with the water vapor profiles obtained by Raman lidar over Athens and the temperature and relative humidity profiles obtained by radiosonde, were incorporated in the thermodynamic model ISORROPIA II (Fountoukis and Nenes, 2007) to determine the aerosol composition. The model treats the thermodynamics of aerosol containing $\mathrm{K}, \mathrm{Ca}, \mathrm{Mg}, \mathrm{NH}_{3} / \mathrm{NH}_{4}, \mathrm{Na}$, $\mathrm{SO}_{4} / \mathrm{HSO}_{4}, \mathrm{HNO}_{3} / \mathrm{NO}_{3}, \mathrm{HCl} / \mathrm{Cl}$ and $\mathrm{H}_{2} \mathrm{O}$. ISORROPIA-II can predict composition for the "stable" (or deliquescent path) solution where salts precipitate once the aqueous phase becomes saturated with respect to a salt, and a "metastable" solution where the aerosol is composed only of an aqueous phase regardless of its saturation state. ISORROPIA-II was executed in "reverse" mode, where known quantities are T, $\mathrm{RH}$ and the concentrations of aerosol $\mathrm{K}, \mathrm{Ca}, \mathrm{Mg}, \mathrm{NH}_{4}, \mathrm{Na}$, $\mathrm{SO}_{4}, \mathrm{NO}_{3}$ and $\mathrm{Cl}$. The output provided by ISORROPIA-II is the aerosol phase state (solid only, solid/aqueous mixture or aqueous only) and the speciation in the gas and aerosol phases. The model has been evaluated with ambient data from a wide range of environments (including "dust-rich") (Moya et al., 2001; Zhang et al., 2003; San Martini et al., 2006; Nowak et al., 2006; Metzger et al., 2006; Fountoukis et al., 2009), while its computational rigor and performance makes it suitable for use in large scale air quality and chemical transport models. Some examples of such 3-D models that have implemented ISORROPIA-II are GISS, CMAQ,

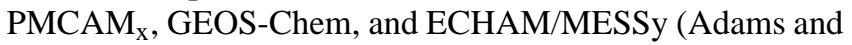


Seinfeld, 2002; Yu et al., 2005; Pye et al., 2009; Karydis et al., 2010; Pay et al., 2010; Pringle et al., 2010).

In order to use ISORROPIA in combination with the Raman lidar data, an assumption concerning the aerosol composition has to be done, mainly due to the absence of air mass sample within the under study layers. This is further corroborated by the fact that the aerosol conditions in the Mediterranean, and especially over Southern Greece are complex (Lelieveld et al., 2002), due to the presence and mixing of aerosols of various origins (marine, Saharan dust, biomass burning events, long-range and/or local pollution) (Sciare et al., 2003; Karageorgos and Rapsomanikis, 2007; Koulouri et al., 2008; Sciare et al., 2008; Pikridas et al., 2010; Terzi et al., 2010; Theodosi et al., 2011). Considering such complexity in aerosol modeling is often important; the output however may be subject to considerable uncertainty.

In our procedure, at first a typical composition of sulfate, ammonium sulfate and mineral dust aerosols was considered. ISORROPIA was run forward for the computation of complex refractive index for each aerosol composition, using as input the relative humidity and the temperature within an aerosol layer. Finally, the aerosol composition (a mixture of sulfate, ammonium and mineral dust) with the closest refractive index (both real and imaginary part) value to the one estimated by the inversion model is provided as the most acceptable composition value.

\subsection{In situ measurements of aerosol properties}

In situ sampling of dust aerosols mixed with urban-like ones was performed to infer the mass concentration and the composition of dust particles near ground. However, under the generally complex aerosol conditions prevailing over S. Greece, as previously mentioned, near surface particle measurements cannot be directly compared to lofted aerosol lidar data, although this could make sense under special conditions (e.g. under very strong Saharan dust events, where the mineral constituents largely dominate the aerosol composition in a homogenized lower troposphere). Our sampling site was installed at the NTUA Campus at the top of a building at 14 $\mathrm{m}$ height from ground level (located $200 \mathrm{~m}$ a.m.s.l.) and included: $\mathrm{PM}_{10}$ continuous concentration monitoring by TSI Dustrak 8520 and TCR TECORA aerosol sampling. The sampling procedure and the elemental composition determinations are described in detail in Remoundaki et al. (2011).

Briefly, $\mathrm{PM}_{10}$ sampling for elemental composition determination and SEM-EDX (Scanning Electron MicroscopeEnergy Dispersive X-ray) analysis was carried out using a TCR TECORA (Sentinel PM) operating at $38.331 \mathrm{~min}^{-1}$, constructed and calibrated in order to comply with European Standard EN12341 for standard sampling of $\mathrm{PM}_{10}$. The sampling device operates with autonomy of 16 samples charged in a charging cassette by programming the sampling span and duration. Aerosol samples were collected on $0.45 \mu \mathrm{m}$ nuclepore membranes. Twelve samples have been collected from
27 March to 2 April 2009. From 28 March to 2 April, two 3-h samples per day were collected: one starting 06:00 UTC and the second starting at 11:00 UTC in order to correspond to urban activities maxima. This 3 -h time span during the two urban activities maxima (beginning and end of working day) was also selected in order to avoid sampling interruption due to filter clogging.

Sampling material and filter keeping petri-dishes were pretreated by soaking in dilute nitric acid solution and thorough rinsing by ultra-pure water $\left(18 \mathrm{M} \Omega \mathrm{cm}^{-1}\right)$ and dried under the laminar flow hood of the laboratory. In order to determine $\mathrm{PM}_{10}$ concentrations, the nuclepore membranes were weighted before and after sampling according to the procedure described in Annex C of EN12341 (EN12341, 1999) using a Mettler Toledo MS105 with a resolution of $10 \mu \mathrm{g}$ in the air conditioned weighing room of the laboratory. The pre-weighted membranes were charged to the filter supports and sampler cassette under the laminar flow hood. Filter blanks and blank field samples were also prepared and analysed together with samples. The filters were also weighted according to the same procedure as described before. The elemental composition determinations have been carried out by using the EDXRF (Energy Dispersive X-Ray Fluorescence) technique (SPECTRO XEPOS bench top XRF spectrometer SPECTRO A.I. GmbH) with Pd end window X-ray tube. NIST standard SRM 2783 has been used for spectrometer calibration verification. The elements $\mathrm{Si}, \mathrm{Al}, \mathrm{Fe}, \mathrm{K}, \mathrm{Ca}, \mathrm{Mg}$, $\mathrm{S}, \mathrm{Ni}, \mathrm{Cu}, \mathrm{Zn}, \mathrm{Mn}$, and Ti, have been determined. SPECTRO $\mathrm{X}$-LAB PRO was used for values normalization and error correction. The method detection limits were $100 \mathrm{ng} \mathrm{cm}^{-2}$ for $\mathrm{Mg}, 20 \mathrm{ng} \mathrm{cm}^{-2}$ for $\mathrm{Al}$ and $\mathrm{K}, 10 \mathrm{ng} \mathrm{cm}^{-2}$ for $\mathrm{Ca}, \mathrm{Ti}, \mathrm{Fe}$, $5 \mathrm{ng} \mathrm{cm}^{-2}$ for $\mathrm{Si}, \mathrm{Mn}, 2 \mathrm{ng} \mathrm{cm}^{-2}$ for $\mathrm{Ni}, 1 \mathrm{ng} \mathrm{cm}^{-2}$ for $\mathrm{S}, \mathrm{Cu}$ and $\mathrm{Zn}$. The estimated precision of the method ranged between $0.1 \%$ and $30 \%$ for individual elements, for most of them being $<5 \%$.

\section{Case study: 27 March-3 April 2009 dust episode}

This case study concerns an intense Saharan dust outbreak, which lasted for eight days (27 March to 3 April 2009) and affected most of the Eastern Mediterranean and Balkans. The ground and remote sensing instruments were operated continuously during this period (although the NTUA Raman lidar was operated during the end of the episode, when clouds were dispersed and aerosol optical depths were low enough to permit sampling by the laser beam. MODIS and CIMEL instruments did not provide aerosol optical depth between 28 March and 1 April, due to extensive cloud cover.

Figure 1 presents the BSC-DREAM predictions of total dust in size classes between 0.1 and $10 \mu \mathrm{m}$ (in $\mathrm{g} \mathrm{m}^{-2}$ ) over the European continent at 12:00 UTC. Superimposed on the same figure are the corresponding hourly forecasted wind vectors at $3000 \mathrm{~m}$ height level. From this figure we see that during the studied period Athens is influenced by high 

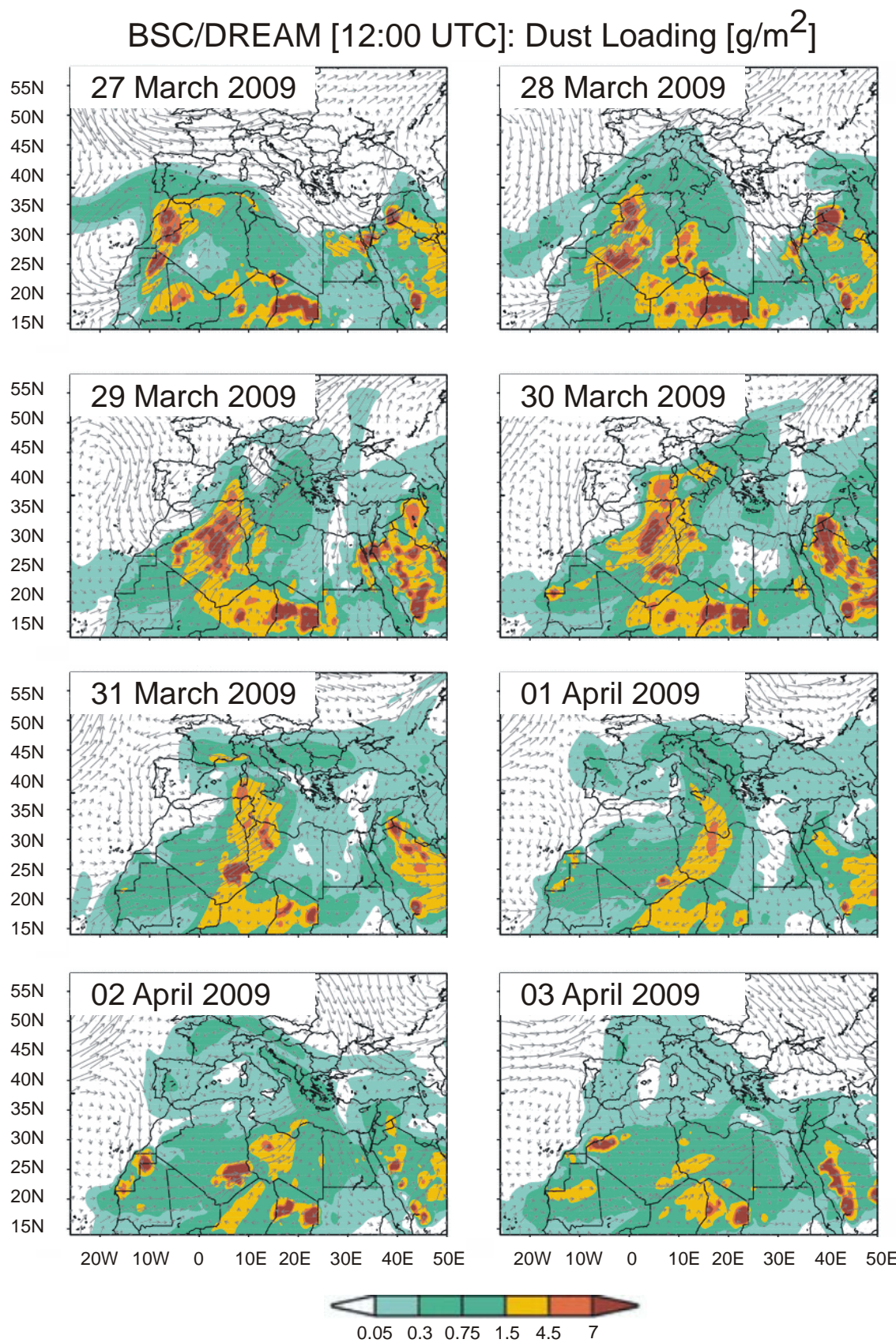

Fig. 1. Dust loading (in $\mathrm{g} \mathrm{m}^{-2}$ ) over Europe in the period between 27 March and 3 April 2009, as estimated by the BSC-DREAM forecast model (12:00 UTC). The wind field pattern is also shown for $3000 \mathrm{~m}$ height level.

values of dust loadings (up to $1.5 \mathrm{~g} \mathrm{~m}^{-2}$ ) from 29 March to 3 April. The maximum dust load was predicted to occur over Athens on 28, 29 March and 2 April (Fig. 1). These large amounts of dust particles originated from the Saharan region and approached Greece after passing over the Mediterranean Sea. Cluster analysis of back-trajectories for air masses arriving in Athens suggests that they may often experience interaction with maritime aerosol before reach- ing the Greater Athens Area (GAA) as indicated by Markou and Kassomenos (2010).

Figure 2 presents the air mass back-trajectories ending over Athens at 1000, 2000 and $3500 \mathrm{~m}$ height levels at 15:00 UTC (left-side figure) and 19:00 UTC (right-side figure) on 2 April, as calculated by the HYSPLIT model (Draxler et al., 2009). These trajectories show that the air masses sampled over Athens had passed 3-7 days earlier from central, western and eastern Sahara (sometimes within 

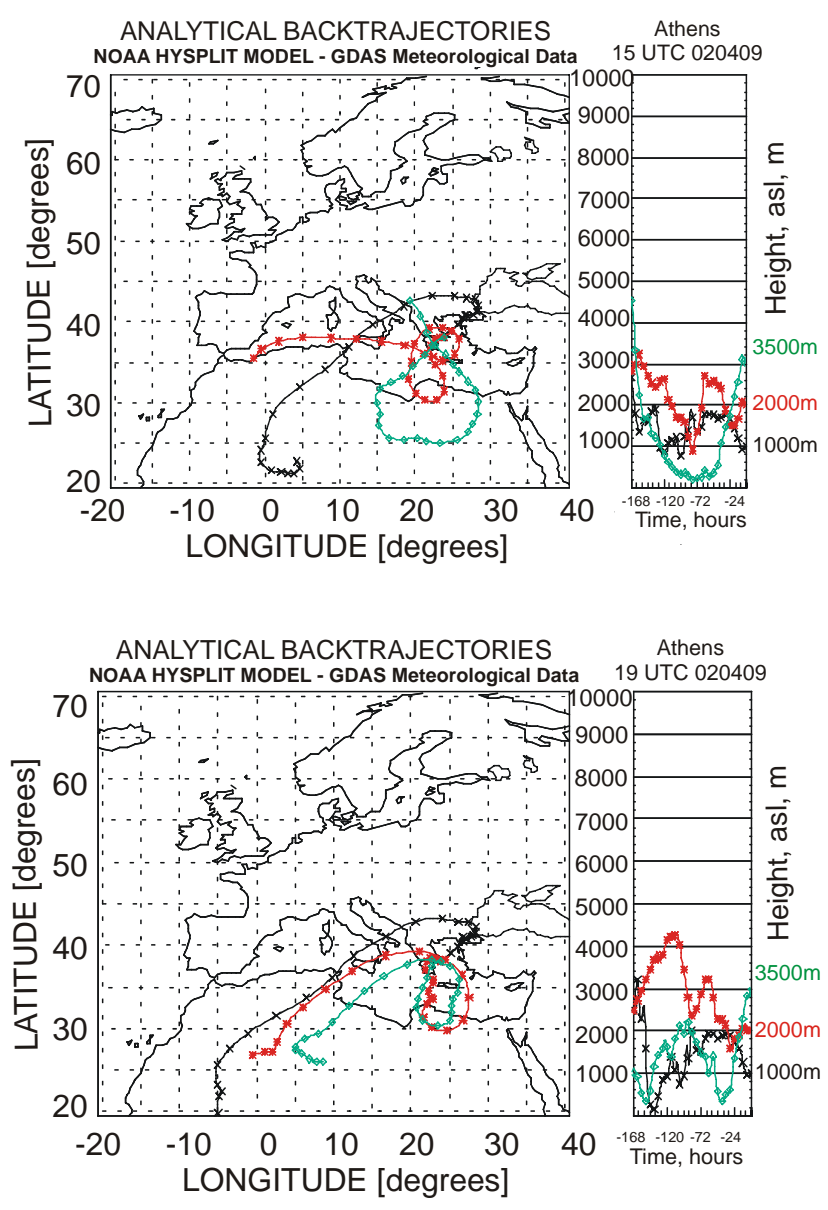

Fig. 2. Seven days air mass back trajectories ending over Athens on 2 April 2009 (left-side: at 15:00 UTC, right-side: at 19:00 UTC) based on the HYSPLIT model.

the Planetary Boundary Layer: PBL), so they were enriched with dust particles. Subsequently, they traversed the central Mediterranean region and moved anti-cyclonically over Greece. More precisely, the air masses ending at $2000 \mathrm{~m}$ height at 15:00 UTC were enriched with Saharan dust particles near the source passing at about $850 \mathrm{~m}$ a.s.l. (about 100 $120 \mathrm{~h}$ before their arrival in Greece), while those ending at $3500 \mathrm{~m}$ nearly touched the surface (some $70-80 \mathrm{~h}$ earlier); thus, they should contain much higher dust loads (Fig. 2, left). On the other hand, the air masses ending at $3500 \mathrm{~m}$ at 19:00 UTC were enriched twice with dust particles passing over the Sahara (about 150 and $30 \mathrm{~h}$, before) (Fig. 2, right). In both figures desert dust particles had the opportunity to mix with marine aerosols and anthropogenic haze (from Italy and the Balkans/Black Sea areas) accumulating over the Mediterranean Sea, which is a common issue in that area (Lelieveld et al., 2002).

Aerosol backscatter and Raman measurements at 355, 532 and $1064 \mathrm{~nm}$ were performed by the NTUA Raman lidar system over Athens only under cloud-free conditions in the stud- ied period. Thus, we will focus on aerosol profiles obtained on 2 April. Figure 3 shows the time-height cross section of the range-corrected backscatter lidar signal (in arbitrary units: AU) obtained at $1064 \mathrm{~nm}$ from 13:42 to 20:49 UTC from 300 up to $6000 \mathrm{~m}$ a.s.l., after the cloud dissipation. According to the lidar measurements, the entire lower troposphere shows a deep, pronounced and aerosol-rich layer extending from ground up to $3500-4000 \mathrm{~m}$ height. More specifically, two thin and distinct aerosol layers are shown. The first layer was located around $2000 \mathrm{~m}$, while the second one was found between $3200-3700 \mathrm{~m}$. Indeed, the BSCDREAM model indicates the transfer of Saharan dust particles over Athens (Fig. 1). These particles are mostly confined between 2000 and $4000 \mathrm{~m}$ height (Fig. 4) and have very high forecasted dust concentrations of the order of $400 \mu \mathrm{g} \mathrm{m}^{-3}$ at $3 \mathrm{~km}$. These dust heights are also in full accordance with the output of the HYSPLIT model indicating the arrival of dustrich air masses over Athens originating from the Saharan desert, then passing over Algeria and Tunisia (Fig. 2). This kind of aerosol structure indicates the presence of aerosols of different origins, as similarly observed during the various campaigns previously cited, such as SAMUM 1 and 2 (Weinzierl et al., 2009; Engelmann et al., 2011; Tesche et al., 2011a), PRIDE, SHADE, DODO1 (McConnell et al., 2008) and DABEX (Heese and Wiegner, 2008; Pelon et al., 2008).

Both aerosol layers detected by lidar slightly descended to lower altitudes with time and became diluted during the afternoon hours (from 13:42 UTC to 16:00 UTC), although always present around $2000 \mathrm{~m}$ and $3200-3700 \mathrm{~m}$. The PBL height during daytime reached heights of about $1400 \mathrm{~m}$ around 14:00 UTC, while during the afternoon hours it descended down to $500 \mathrm{~m}$ a.s.l. around midnight, in full accordance with the closest radiosonde profile data (not shown here). The highest values of the range-corrected backscatter lidar signal within the PBL (shown by the red color in Fig. 3), under stable relative humidity values, indicate the possibility of dust presence also near ground, mixed with locally produced aerosols (e.g. by anthropogenic sources) (Balis et al., 2006). This was confirmed by Remoundaki et al. (2011), since the mass concentration of $\mathrm{PM}_{10}$ particles measured in situ at $14 \mathrm{~m}$ a.g.l., from 27 March to 2 April, showed that during this dust event when the aerosol rich air masses touched the ground, the aerosol mass concentrations exceeded 140$160 \mu \mathrm{g} \mathrm{m}^{-3}$, from 30 March to 1 April. During noon and early afternoon hours of 2 April, $\mathrm{PM}_{10}$ concentrations at ground reached $60-70 \mu \mathrm{g} \mathrm{m}^{-3}$, consistent with the lidar data concerning the detection of the arrival of the dust layers over Athens (Fig. 3). The BSC-DREAM model correctly simulated the existence of a dust layer centred around $3 \mathrm{~km}$ (at 18:00 UTC) and extending up to $4000-4500 \mathrm{~m}$ height (Fig. 4), although it did not correctly simulate the profile of the aerosol mass concentration near ground $\left(25 \mu \mathrm{g} \mathrm{m}^{-3}\right.$ measured versus $10 \mu \mathrm{g} \mathrm{m}^{-3}$ simulated, while annual mean $\mathrm{PM}_{10}$ mass concentrations in Athens on 2009 were of the order of $26 \pm 1 \mu \mathrm{g} \mathrm{m}^{-3}$, YPEKA, 2010). This is because the BSC- 


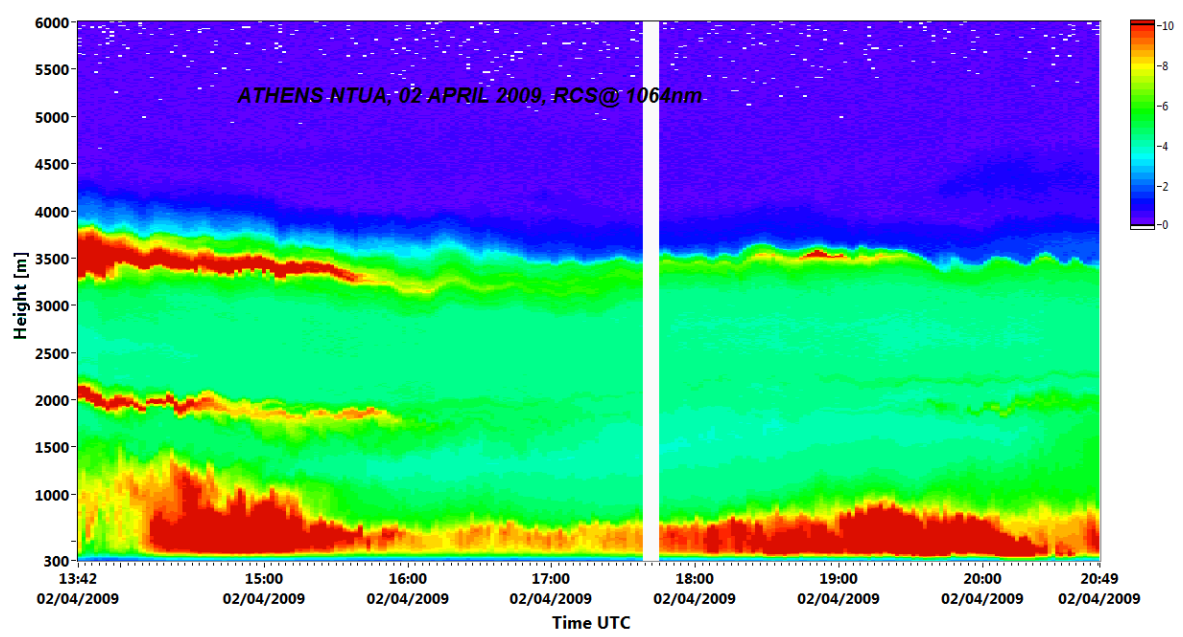

Fig. 3. Time-height cross section of the range-corrected backscatter lidar signal (in arbitrary units: AU) at $1064 \mathrm{~nm}$, as observed over Athens, by the NTUA Raman lidar system on 2 April 2009 (13:42-20:49 UTC).

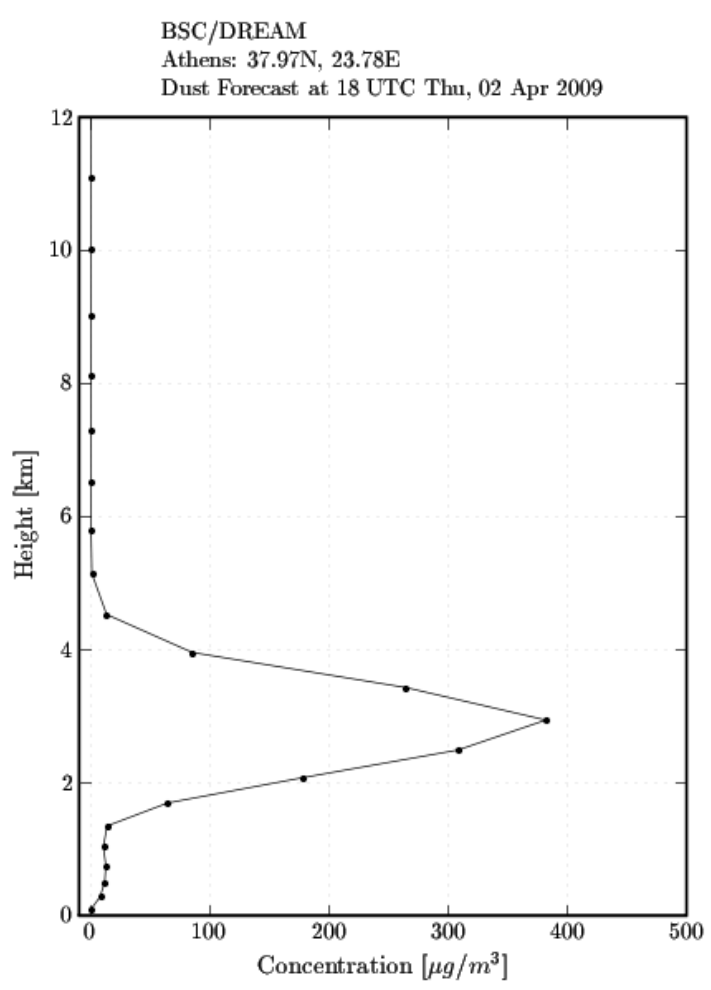

Fig. 4. Forecast of the vertical profile of the dust concentration (in $\mu \mathrm{g} \mathrm{m}^{-3}$ ) over Athens, Greece for 2 April 2009, at 18:00 UT using the BSC-DREAM model.

DREAM simulates only the dust-related aerosol profiles and not those related to air pollution urban sources.

In Fig. 5 the corresponding vertical profiles of the aerosol optical properties ( $a_{\mathrm{aer}}, b_{\mathrm{aer}}, \mathrm{LR}, \mathrm{ABR}$ and AER), as well as the water vapour mixing ratio (WVMR) are presented, along with the respective error bars. The averaging time of the lidar signals for the retrieved vertical profiles is approximately $3 \mathrm{~h}$ and the vertical range resolution is of the order of $15 \mathrm{~m}$. We note here, that the lower height of our aerosol retrievals is around $1500 \mathrm{~m}$ a.s.l., due to the overlap height of our lidar system, which is of the order of 1200-1500 m, depending on the wavelength used. Based on the aerosol extinction and backscatter profiles shown in Fig. 5, the presence of particles (between 17:40-20:40 UTC) extends mainly up to $3500 \mathrm{~m}$, coinciding with decreased values $(1.11 \pm 0.02)$ of the $\mathrm{ABR}_{532 / 1064}$ (red line in Fig. 5) between 1500 and $4000 \mathrm{~m}$, indicating the presence of rather small particles $(0.1 \mu \mathrm{m}<$ diameter $<1 \mu \mathrm{m})$ (Müller et al., 2003; Ansmann et al., 2002; Tesche et al., 2011b). The corresponding water vapour vertical profile derived by the NTUA Raman lidar showed that its mixing ratio remained of the order of $4 \mathrm{~g} \mathrm{~kg}^{-1}$ inside the dust layer. Moreover, the relative humidity $(\mathrm{RH})$ profile obtained by radiosonde at a nearby location (about $15000 \mathrm{~m}$ away) showed RH humidity values (79$80 \%$ ) around the $3000 \mathrm{~m}$ height region, which could lead to a probable mixing of the dust particles with humidity.

The mean LR values found over Athens inside the referred aerosol layers in the height range between 1800 and $3500 \mathrm{~m}$ height were $83 \pm 7 \mathrm{sr}(355 \mathrm{~nm})$ and $54 \pm 7 \mathrm{sr}(532 \mathrm{~nm})$; while the $\mathrm{ABR}_{355 / 532}$ and $\mathrm{AER}_{355 / 532}$ values, were $1.17 \pm 0.08$ and $1.11 \pm 0.02$, respectively (Table 1 ). Indeed, the aerosol optical properties presented in Fig. 5, support our view about mixing of dust with other particles, since our measured LR, $\mathrm{ABR}_{355 / 532}$ and $\mathrm{AER}_{355 / 532}$ values are higher than those for pure dust which are close to $53 \pm 7 \mathrm{sr}(355 \mathrm{~nm}), 55 \pm 7 \mathrm{sr}$ $(532 \mathrm{~nm}), 0.2 \pm 0.2$, and $0.0 \pm 0.2$, respectively, according to Tesche et al. (2009a) (see Table 1). Therefore, as our LRs are higher than 53-55 sr and $\mathrm{ABR}_{355 / 532}$ and $\mathrm{AER}_{355 / 532}$ values are greater than 1 , the particles probed should be a 


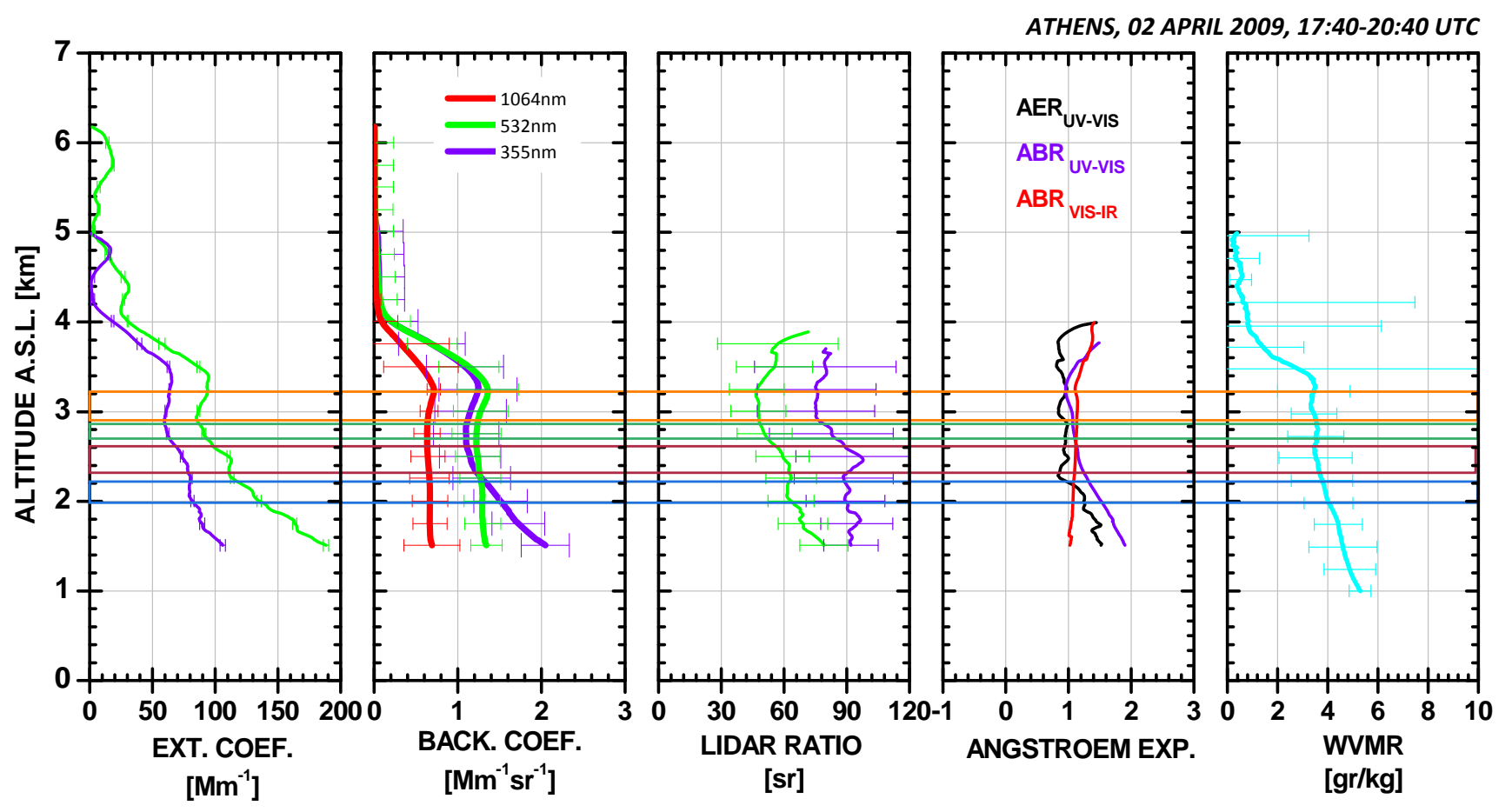

Fig. 5. Vertical profiles of the aerosol optical properties (extinction and backscatter coefficient, lidar ratio and Ångström backscatter- and extinction-related exponent), as well as of the water vapor to dry air mixing ratio $\left(\mathrm{g} \mathrm{kg}^{-1}\right)$ (with error bars), as retrieved by the NTUA Raman lidar over Athens on 2 April 2009 (17:40-20:40 UTC).

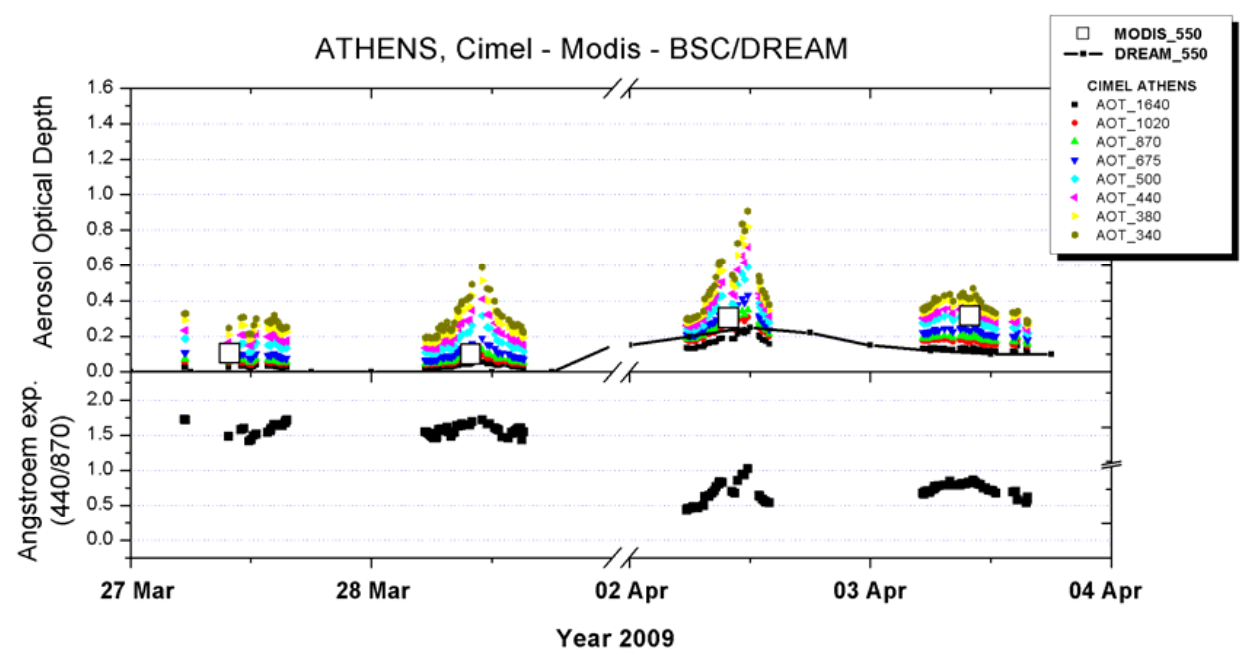

Fig. 6. Temporal evolution of the AOD at eight wavelengths over Athens for the period 27 March to 4 April 2009 according to CIMEL sunsky radiometer, MODIS at $550 \mathrm{~nm}$ (white squares) and BSC-DREAM model at $550 \mathrm{~nm}$ (upper panel). Temporal evolution of the Ångström exponent $(440 / 870 \mathrm{~nm})$ for the same time period (lower panel).

mixture of dust ( $\left.\mathrm{AER}_{355 / 532} \sim 0\right)$ and other particles, such as continental haze and smoke (AER $355 / 532 \sim 1.4-2$ ) (see references in Table 1 and also Ansmann et al., 2001; Franke et al., 2003; Müller et al., 2003, 2004, 2011; Amiridis et al., 2009b, 2012; Burton et al., 2012). This is further supported by the
MODIS hot spot fire product (http://modis.higp.hawaii.edu/ cgi-bin/modis/modisnew.cgi) indicating biomass burning activity along the air mass trajectory path given in Fig. 2 . 
Table 1. Raman lidar-derived mean aerosol optical properties $\left(\mathrm{LR}_{355}, \mathrm{LR}_{532}, \mathrm{ABR}_{355 / 532}, \mathrm{AER}_{355 / 532}\right)$ obtained from different campaigns or systematic measurements).

\begin{tabular}{llllll}
\hline $\mathrm{LR}_{355}(\mathrm{sr})$ & $\mathrm{LR}_{532}(\mathrm{sr})$ & $\mathrm{ABR}_{355 / 532}$ & $\mathrm{AER}_{355 / 532}$ & Aerosol type & Reference \\
\hline $83 \pm 7$ & $54 \pm 7$ & $1.17 \pm 0.08$ & $1.11 \pm 0.02$ & Dust + haze + smoke & This study \\
$60 \pm 10$ & $50 \pm 13$ & N/A & N/A & Haze + smoke & Balis et al. (2003) \\
$71 \pm 8$ & $79 \pm 10$ & N/A & $1.46 \pm 0.30$ & Haze & Noh et al. (2007) \\
$58 \pm 12$ & $53 \pm 11$ & $1.4 \pm 0.5$ & N/A & Haze & Müller et al. (2007) \\
$75 \pm 15$ & N/A & N/A & N/A & Smoke & Heese and Wiegner, 2008 \\
$45 \pm 25$ & N/A & $1.4 \pm 0.5$ & N/A & Dust +haze + & Papayannis et al. (2008) \\
& & & & maritime & (Thessaloniki station, only) \\
$65 \pm 16$ & N/A & $1.7 \pm 0.6$ & N/A & Smoke & Amiridis et al. (2009) \\
$56 \pm 7$ & $63 \pm 7$ & $0.92 \pm 0.59$ & N/A & Smoke & Noh et al. (2009) \\
$56 \pm 7$ & $59 \pm 10$ & $0.87 \pm 0.14$ & N/A & Haze & Noh et al. (2009) \\
$75 \pm 7$ & $75 \pm 7$ & $0.7 \pm 0.2$ & $0.8 \pm 0.3$ & Dust + smoke & Ansmann et al. (2009) \\
$53 \pm 7$ & $55 \pm 7$ & $0.2 \pm 0.2$ & $0.0 \pm 0.2$ & Dust & Tesche et al. (2009a) \\
$69 \pm 17$ & N/A & $1.0 \pm 0.7$ & N/A & Smoke & Giannakaki et al. (2010) \\
$75 \pm 9$ & $69 \pm 8$ & N/A & $1.07 \pm$ N/A & Dust + smoke & Gross et al. (2011) \\
$67 \pm 14$ & $67 \pm 12$ & $0.71 \pm 0.28$ & $0.67 \pm 0.38$ & Dust + smoke & Tesche et al. (2011a) \\
$74 \pm 09$ & $69 \pm 10$ & $0.63 \pm 0.19$ & $0.76 \pm 0.31$ & Dust + smoke & Tesche et al. (2011b) \\
$87 \pm 17$ & $79 \pm 17$ & $0.90 \pm 0.26$ & $1.15 \pm 0.28$ & Smoke & Tesche et al. (2011b) \\
\hline
\end{tabular}

Figure 6 shows the temporal evolution of the CIMEL sunsky radiometer AOD at eight wavelengths and the Ånsgtröm exponent $(\alpha)$ over Athens for the period 27 March to 3 April 2009. The value of $\alpha$ is derived according to the Ångström power law, using the 440,670 and $870 \mathrm{~nm}$ channels (e.g. Eck et al., 1999; Holben et al., 2001). From the almucantar sky radiance measurements (see also http://aeronet.gsfc. nasa.gov) at the four highest wavelengths an inversion algorithm (AERONET version 2), as described by Dubovik et al. (2002 and 2006), retrieves a large set of optical and microphysical aerosol parameters. In Fig. 6, the MODIS AODs at $550 \mathrm{~nm}$ are additionally presented (white squares) along with the BSC-DREAM dust AODs at $550 \mathrm{~nm}$ (upper panel). CIMEL data between 29 March and 1 April are lacking owing to excessive cloud cover over the city of Athens.

Moreover, the MODIS data for the GAA $(10 \mathrm{~km} \times 10 \mathrm{~km}$ over the station) on March 29 (not shown) showed that the evolution of the event was well captured by the BSCDREAM model. The BSC-DREAM AODs data (Fig. 6) showed the quick arrival of the desert plume over the Athens station on 29 March and then on 2 April. The highest CIMEL AOD was registered on 2 April with a value of $0.90 \pm 0.05$ $(340 \mathrm{~nm})$. The desert dust plume was also visible on 3 April, while the following days (from 4 April) showed a clear weakening of the event as the desert plume quickly moved away, as shown by the AOD, which dropped back to background levels of around 0.3 at $340 \mathrm{~nm}$ in accordance with the mean annual AOD $(0.29 \pm 0.18)$, reported for Athens at $440 \mathrm{~nm}$ by Gerasopoulos et al. (2011). We have to mention here that the same authors report that the mean AOD at $500 \mathrm{~nm}$ for Athens is 0.34 during stagnant conditions where anthropogenic haze dominates (Gerasopoulos et al. (2011). Therefore, back-

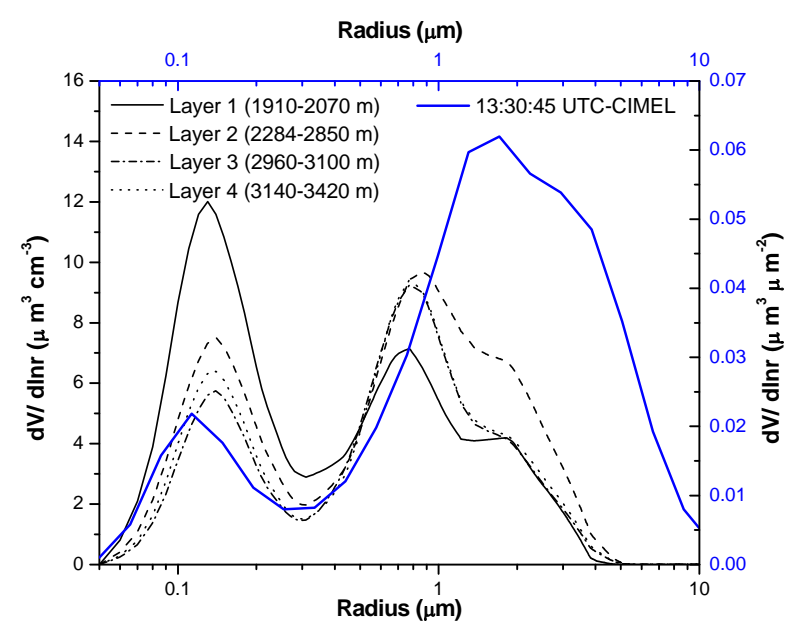

Fig. 7. Retrieved aerosol volume size distribution from the NTUA Raman lidar data for radiuses up to $10 \mu \mathrm{m}$, for the particles in layers 1 (1910-2070 m), 2 (2284-2850 m), 3 (2960-3100 m) and 4 (3140$3420 \mathrm{~m}$ ) between 17:40-20:40 UTC (left vertical axis). Measured aerosol volume size distribution (total column) by the CIMEL sunsky radiometer on 2 April 2009, at 13:30 UTC. (right vertical axis).

ground AODs are slightly lower than those reported for local haze conditions, and much lower for dust conditions $(\mathrm{AOD}>0.4)$. The temporal evolution of the Ångström exponent $(440-870 \mathrm{~nm})$ for the same time period is also shown in the lower panel, showing low values (from 0.4 to 1.0) for 2 and 3 April, in inverse correspondence with the high AOD for desert aerosols. One of the characteristics of the desert dust episodes in our area (Balis et al., 2004) is the high variability shown by both parameters during each day. 
As can be seen in Fig. 6, on 2 April between 10:00 and 14:00 UTC, we observed high AODs due to thick dust layers which were advected to the observation location (as shown in lidar data). For the same day, the mean daily volume aerosol size distribution (not shown) exhibited two modes, but the relative importance of the modes depends on the prevailing aerosol type: an accumulation or fine mode with particle radius below $0.6 \mu \mathrm{m}$, and a coarse mode with particle radius between 0.6 and $15 \mu \mathrm{m}$. In this case, we expect a predominant coarse mode during desert dust conditions. The mode radii and volume concentrations were analysed in order to characterize the aerosol dust evolution. The evolution of the desert dust is clear in the coarse mode fraction.

Table 2 presents the percentual contribution of dust and sulfates to $\mathrm{PM}_{10}$ at near ground level. The detailed calculations have already been presented in Remoundaki et al. (2011). From this Table, it can be seen that dust contribution was at the level of $15 \%$ before the arrival of the Saharan dust and increased significantly during the dust event reaching $65 \%$ on 31 March and $79 \%$ on 1 April, respectively. Sulfates contribution $\left(\mathrm{SO}_{4}^{2-}\right)$ was in expected levels for the city of Athens (Karageorgos and Rapsomanikis, 2007; Theodosi et al., 2011) and presented a maximum on March 29 where southerlies (responsible for long-range transport of particles of crustal origin) were simultaneously present with west winds charged with aerosol particles from local urban and industrial emission sources (e.g. oil refineries of Aspropyrgos located in the WNW-NW sector) (Remoundaki et al., 2011). Finally, both dust and sulfates represent significant fraction of $\mathrm{PM}_{10}$ and account in some cases for more than $50 \%$ of the $\mathrm{PM}_{10}$ mass.

Indeed, the EDX analysis of all particles sampled (Remoundaki et al., 2011) during the reported period (27 March to 3 April 2009), revealed that aluminosilicates (clays) were predominant. The presence of illite was clear in many cases, quartz particles were rare and very difficult to be detected. Dust particles were very rich in calcium which is distributed between calcite, dolomite and sulfates and $\mathrm{Ca}-\mathrm{Si}$ particles (e.g. smectites). Iron oxides were often detected. These results are in very good agreement and confirm those reported on the elemental composition of the dust and the origins of the air masses which first started from the Western Sahara and passed over northern Algeria on their way to Greece. These findings are also in very good agreement with literature on the Saharan particles characterization and their relationship to their origins (Coude-Gaussen et al., 1987; Avila et al., 1997; Blanco et al., 2003; Coz et al., 2009; Rodríguez et al., 2011).

Using the aerosol backscatter profiles at 355, 532 and $1064 \mathrm{~nm}$ and the corresponding aerosol extinction profiles at 355 and $532 \mathrm{~nm}$, we calculated the aerosol microphysical properties with the retrieval code for spheroid particles (Veselovskii et al., 2010) using the lidar data of 2 April. As mentioned previously, the retrieval algorithm represents the aerosol as a mixture of spheres and spheroids. How- ever, without using the particle depolarization ratio in retrieval, the spheroid volume ratio (SVR) is underestimated, which leads to the underestimation of the real part of refractive index (Mishchenko and Hovenier, 1995; Veselovskii et al., 2010). Thus, it is more accurate to suggest that the majority of the particle volume in the considered height range is related to non spherical particles. This assumption is justified by the HYSPLIT trajectories, which suggest that most of the particles in the coarse mode are associated with dust. The finer mode particles (and a fraction of the coarse dust) are expected to mix with anthropogenic pollution and sea salt; this, together with aerosol water will undoubtfully make particles more spherical.

We selected to retrieve the aerosol properties at four different layers for the period between 17:40-20:40 UT: layer 1 (1910-2070 m), layer 2 (2284-2850), layer 3 (2960-3100 m) and layer $4(3140-3420 \mathrm{~m})$. The retrieved particle volume size distributions $\mathrm{dV} / \mathrm{dln}$ for the four considered layers is shown in Fig. 7 (left-hand graph). Moreover, the integral particle parameters, such as $V, S, N, r_{\text {eff }}$ and $m_{R}$ and $m_{i}$ are summarized in Table 3. From the particle size distribution (PSD) analysis, shown in Fig. 7 we can conclude that the fine mode of the PSD is centered at $0.13 \mu \mathrm{m}$, while the coarse mode is centered near 1 and $2 \mu \mathrm{m}$. More specifically, at lower heights (layer 1) the fine mode is prevailing, but at higher altitudes the contribution of the coarse mode becomes more important. The fine mode containing the small particles determines the integral particle number density. In our case, the fine mode particles decrease with height, thus resulting in $N$ decreasing from $1700 \mathrm{~cm}^{-3}$ in layer 1 , to 700 $800 \mathrm{~cm}^{-3}$ in layers 3 and 4 . On the other hand, the mean effective radius rises from $0.22 \mu \mathrm{m}$ to around $0.32 \mu \mathrm{m}$ between layer 1 and layers 3 and 4 . In fact, the in situ aerosol sampling near ground revealed that near the end of the Saharan dust event on 2 April, the dominant size of the particles diameter was smaller than $2 \mu \mathrm{m}$ (Remoundaki et al., 2011), which is consistent with the retrieved entire aerosol volume size distribution (Fig. 7). Additionally, in Fig. 7 (right-hand graph in blue color) we show the aerosol size distribution (total column) measured by the CIMEL sun-sky radiometer for different hours (from 05:55:42 UTC to 13:30:45 UTC) where two main aerosol classes are found: those of fine mode (around $0.15 \mu \mathrm{m}$ radius, in agreement with those obtained in the aerosol characterization from direct-sun AERONET data presented in Basart et al., 2009) and those of coarse mode particles (around $1-2 \mu$ m radius).

Furthermore, if we divide the integrated CIMEL data (at 13:30:45 UTC) by the dust layer thickness of about 3.5-4 km, we obtain maxima of the $\mathrm{dV}(\mathrm{r}) / \mathrm{dln}(\mathrm{r})$ of the order of 5.5-6.2 and $15-17 \mu \mathrm{m}^{3} \mathrm{~cm}^{-3}$ for the fine and coarse mode, respectively. These maximum values are quite close (especially the fine mode ones) to the maximum size distribution values (Fig. 7) retrieved from the lidar data (5.5-12 and 7$10 \mu \mathrm{m}^{3} \mathrm{~cm}^{-3}$, for the fine and coarse mode, respectively). Moreover, our retrieved aerosol size distribution and the one 
Table 2. Percentage of mineral dust (MIN) and sulfates contribution in $\mathrm{PM}_{10}$ (27/03-02/04) (Remoundaki et al., 2011): time-height cross section of the range-corrected backscatter lidar signal (in arbitrary units: AU) at $1064 \mathrm{~nm}$, as observed over Athens, by the NTUA Raman lidar system on 2 April 2009 (13:42-20:49 UTC).

\begin{tabular}{lrrrr}
\hline Date & $\begin{array}{r}\mathrm{PM}_{10} \\
\left(\mu \mathrm{g} \mathrm{m}^{-3}\right)\end{array}$ & $\% \mathrm{MIN}$ & $\% \mathrm{SO}_{4}$ & $\begin{array}{r}\% \mathrm{TOT} \\
\left(\mathrm{MIN}+\mathrm{SO}_{4}\right)\end{array}$ \\
\hline $27 / 3 / 2009$ & 17 & 19.0 & 27.4 & 46.4 \\
$28 / 3 / 2009$ & 39 & 18.7 & 13.4 & 32.2 \\
$28 / 3 / 2009$ & 17 & 17.0 & 32.3 & 49.3 \\
$29 / 3 / 2009$ & 17 & 15.1 & 29.4 & 44.5 \\
$29 / 3 / 2009$ & 14 & 13.3 & 45.6 & 58.9 \\
$30 / 3 / 2009$ & 68 & 34.4 & 16.1 & 50.4 \\
$31 / 3 / 2009$ & 62 & 64.7 & 14.3 & 79.0 \\
$31 / 3 / 2009$ & 62 & 39.8 & 22.2 & 62.0 \\
$1 / 4 / 2009$ & 57 & 45.7 & 14.7 & 60.4 \\
$1 / 4 / 2009$ & 32 & 78.9 & 17.5 & 96.4 \\
$2 / 4 / 2009$ & 54 & 34.5 & 17.5 & 52.0 \\
\hline
\end{tabular}

from CIMEL show comparable size distributions having radius centered on $0.13 \mu \mathrm{m}$ (fine mode) and 1 to $2 \mu \mathrm{m}$. Although there is some difference, especially in the coarse mode (around 1-2 $\mu \mathrm{m}$ radius) particles, temporal variability and non concurrent measurements between the retrievals could account for it.

Additionally, the retrieved real part of the refractive index is of the order of 1.47 for the layers 1 and 2, indicating mixing of dust with urban-like sulfate and organic carbon aerosols (Sokolik et al., 1993; Ebert et al., 2004; Raut and Chazette, 2008; McConnell et al., 2010), while for the layers 3 and 4 it increases up to 1.52, indicating the even stronger mixing of dust with organic carbon aerosols and urban-like sulfate over Athens (Ebert et al., 2002; Petzold et al., 2009). The imaginary part of refractive index in all layers is $m_{i}=0.007 \pm 0.0035$, indicating aerosol that is internally mixed with slightly absorbing dust (Patterson et al., 1977; Sokolik et al., 1993; Sokolik and Toon, 1999; Ebert et al, 2004; T. Müller et al., 2009; Kandler et al., 2009).

It is interesting to note that the latest available CIMEL data for 2 April, obtained at 13:30 UTC over Athens (not shown here), gave a columnar refractive index of the order of 1.53-1.55 (real part), while the imaginary part was ranging from $0.009 \mathrm{i}$ to $0.015 \mathrm{i}$. These values represent column values which are obtained during the Saharan dust event several hours before the lidar sampling; they are typical of mixtures of silicate particles with sea salt (Ebert et al., 2002). Moreover, the retrieved mean columnar value of the effective radius was $0.21 \mu \mathrm{m}$ (at 13:30:45 UTC), which compares very well with the retrieved value $(0.22 \mu \mathrm{m})$, from the lidar data at the dust layer 1 (between 17:40-20:40 UTC), but less with those retrieved from layers $2-4(2.28-3.42 \mathrm{~km})$, as shown in Table 3. Indeed, layers 2 to 4 (17:40 to 20:40 UTC) are related to the strong dust layer which appeared around $3.5 \mathrm{~km}$ (from 13:42 to 16:00 UTC) (see Fig. 3), therefore, they could be probably associated to bigger dust particles.

The final data set of the aerosol optical and microphysical properties along with the water vapour profiles were incorporated into the ISORROPIA II model (Fountoukis and Nenes, 2007), to provide a possible dry chemical composition that is consistent with the retrieved refractive index values (Table 3 ). Of course, due to the complexity of the aerosols probed over Athens, a unique "solution" for the chemical composition cannot be provided, unless in situ airborne data are available for direct comparison to validate our model results. For the aerosols located at layer 1 , we derived a chemical composition of about 50-60\% sulfate, 15-25\% organic carbon (OC) and 15-35\% mineral dust is required for this. At the second layer, the model showed less concentration of sulfates and a slight increase of OC in comparison with the first one. Specifically, the retrieved chemical composition was of the order of $32-52 \%$ for sulfates, $28-36 \%$ for the OC and $12-40 \%$ mineral dust. For the aerosols located at layer 3 we derived a chemical composition of about $18-38 \%$ sulfate, $52-62 \%$ OC and 0-30\% mineral dust. For the aerosols located at layer 4 a chemical composition of about 16-36\% sulfate, 54-64\% OC and 0-30\% mineral dust was estimated by the model. At the two upper layers the retrievals showed more concentration of $\mathrm{OC}$ which is correlating well with the high values of the refractive index (of the order of 1.52) and is consistent with the enrichment of organics in the aerosol that is often seen in the free troposphere (Heald et al., 2005).

These findings, which indeed indicate mixing of mineral dust aerosols with sulfate and OC ones (typical from urban air pollution sources and biomass burning), are in accordance with the lidar data presented in Fig. 3 where the dust layered aerosols around 2000-3500 m (between 17:4020:40 UT) are diluted over the PBL, through mixing with locally produced ones. Table 3 summarizes the optical, microphysical and chemical properties of aerosols retrieved at the four specific layers (1st to 4th layer) as well as the RH (\%) at each layer for 2 April 2009. Regarding the percentage of mineral dust (34.5\%) to $\mathrm{PM}_{10}$ shown in Table 2, we see that the findings from the chemical analysis are in the upper limit values of those derived by the ISORROPIA II model for the lower atmospheric layers (1st and 2nd layers, located from 1.9 to $2.85 \mathrm{~km}$ a.s.l.). Given that $\mathrm{OC}$ is not measured, $34.5 \%$ is in reality the upper limit of dust concentration.

On the other hand, the percentage of $\mathrm{SO}_{4}$ contribution to $\mathrm{PM}_{10}$ near ground (see Table 2) was much lower than the ones derived by the ISORROPIA II model for the lower atmospheric layers, but it agreed quite well with the lower limit values of those derived by the ISORROPIA II model for the upper atmospheric layers (3rd and 4th layers, located from 2.9 to $3.42 \mathrm{~km}$ a.s.l.). Given that the filter integrates over a larger period than the lidar (Remoundaki et al., 2011), the average chemical composition differs from the retrieval: furthermore, changes in acidity (due to uptake of 
Table 3. Mean optical, microphysical and chemical properties of aerosols, as well as the relative humidity RH (\%) at each layer, retrieved at four specific layers on 2 April 2009.

\begin{tabular}{|c|c|c|c|c|}
\hline & 1st layer & 2nd layer & 3rd layer & 4th layer \\
\hline Height range (km) & $1.91-2.07$ & $2.28-2.85$ & $2.96-3.10$ & $3.14-3.42$ \\
\hline Lidar Ratio@355nm (sr) & $89.8 \pm 0.60$ & $89.0 \pm 5.50$ & $75.2 \pm 0.16$ & $76.7 \pm 1.60$ \\
\hline Lidar Ratio@ @ 532 nm (sr) & $64.0 \pm 2.00$ & $56.6 \pm 5.00$ & $47.8 \pm 0.09$ & $48.4 \pm 1.90$ \\
\hline $\mathrm{AER}_{355 / 532}$ & $1.250 \pm 0.008$ & $0.935 \pm 0.043$ & $0.849 \pm 0.010$ & $0.936 \pm 0.024$ \\
\hline $\mathrm{ABR}_{355 / 532}$ & $1.52 \pm 0.05$ & $1.14 \pm 0.06$ & $1.03 \pm 0.02$ & $0.97 \pm 0.02$ \\
\hline $\mathrm{ABR}_{532 / 1064}$ & $1.070 \pm 0.003$ & $1.11 \pm 0.01$ & $1.140 \pm 0.004$ & $1.13 \pm 0.02$ \\
\hline Refractive Index (real part) & $1.47 \pm 0.05$ & $1.47 \pm 0.05$ & $1.51 \pm 0.05$ & $1.52 \pm 0.05$ \\
\hline Refractive Index (imaginary part) & $0.0070 \pm 0.0035$ & $0.0070 \pm 0.0035$ & $0.0070 \pm 0.0035$ & $0.0070 \pm 0.0035$ \\
\hline Mean effective $\operatorname{radius}(\mu \mathrm{m})$ & $0.22 \pm 0.06$ & $0.32 \pm 0.10$ & $0.33 \pm 0.10$ & $0.31 \pm 0.10$ \\
\hline Surface density $\left(\mu \mathrm{m}^{2} \mathrm{~cm}^{-3}\right)$ & $290 \pm 60$ & $210 \pm 45$ & $150 \pm 30$ & $170 \pm 35$ \\
\hline Number density $\left(\mathrm{cm}^{-3}\right)$ & $1700 \pm 1000$ & $1100 \pm 700$ & $700 \pm 400$ & $800 \pm 500$ \\
\hline Volume density $\left(\mu \mathrm{m}^{3} \mathrm{~cm}^{-3}\right)$ & $21 \pm 6.5$ & $22 \pm 6.5$ & $17 \pm 5.0$ & $17 \pm 5.0$ \\
\hline $\mathrm{RH}(\%)$ & 59 & 64 & 79 & 80 \\
\hline Chemical composition & $\begin{array}{r}50-60 \% \text { sulfate, } \\
15-25 \% \text { OC, } \\
15-35 \% \text { dust }\end{array}$ & $\begin{array}{r}32-52 \% \text { sulfate } \\
28-36 \% \text { OC, } \\
12-40 \% \text { dust }\end{array}$ & $\begin{array}{r}18-38 \% \text { sulfate } \\
52-62 \% \text { OC, } \\
0-30 \% \text { dust }\end{array}$ & $\begin{array}{r}16-36 \% \text { sulfate, } \\
54-64 \% \text { OC, } \\
0-30 \% \text { dust }\end{array}$ \\
\hline
\end{tabular}

ammonium) affect the mass associated with the sulfate ion by $40 \%$ (Seinfeld and Pandis, 2008).

\section{Conclusions}

In this manuscript, we attempted to combine experimental data (multi-wavelength Raman data ( 3 aerosol backscatter and 2 extinction profiles) and in situ measurements to chemically characterize the aerosol sampled) and models (microphysical inversion and thermodynamic ones) to infer the particle optical and microphysical properties, as well as a possible chemical composition.

During a strong Saharan dust event that occurred over Athens (27 March to 3 April 2009), selected measurements were performed to obtain the optical properties of the dust particles in the lower free troposphere. A hybrid regularization technique was used to derive the mean microphysical properties of the dust particles, while the thermodynamic model ISORROPIA II was used to provide possible aerosol chemical properties at four selected dust layers between 2.9 and $3.4 \mathrm{~km}$. AOD values, derived from the CIMEL sun-sky radiometer, ranged from $0.33-0.91(340 \mathrm{~nm})$ to $0.18-0.60(500 \mathrm{~nm})$, while the LR values retrieved from the Raman lidar ranged from $75-100 \mathrm{sr}(355 \mathrm{~nm})$ and $45-$ $75 \mathrm{sr}(532 \mathrm{~nm})$. Moreover, $\mathrm{ABR}_{355 / 532}$ and $\mathrm{ABR}_{532 / 1064}$ values of about 0.9-1.9 and 1.0-1.45 were observed, respectively, while the $\mathrm{AER}_{355 / 532}$ ranged within 0.8-1.5. Inside selected dust layers, mean $\mathrm{AER}_{355 / 532}$ ranged within $0.85-$ 1.25 , while the mean LR values were $83 \pm 7 \mathrm{sr}(355 \mathrm{~nm})$ and $54 \pm 7 \mathrm{sr}(532 \mathrm{~nm})$ and the mean $\mathrm{ABR}_{355 / 532}$ and $\mathrm{AER}_{355 / 532}$ were $1.17 \pm 0.08$ and $1.11 \pm 0.02$, respectively. The higher mean value of $\mathrm{AER}_{355 / 532}$ (1.25) observed at the lower atmospheric layer indicates the presence of smaller particles, compared to those at higher layers where we have larger particles, since their $\mathrm{AER}_{355 / 532}$ were much lower (0.85-0.94). The presence of pure dust can be easily excluded since it is characterized by AER and ABR values lower than 0.5 (Tesche et al., 2011a). The presence of smaller particles at the lower layer, under this strong dust event, indicates a possible mixing of haze and dust, while the larger particles at higher heights may indicate the mixing of dust with coarser particles. Indeed, inside the four selected dust layers the aerosol refractive indexes ranged from $1.47( \pm 0.05)+0.0070( \pm 0.0035) \mathrm{i}$ to $1.52( \pm 0.05)+0.0070( \pm 0.0035) \mathrm{i}$, while effective radiuses ranging from $0.22 \pm 0.06$ to $0.33 \pm 0.10 \mu \mathrm{m}$ were retrieved.

In the first two lower atmospheric layers, the inferred possible contribution of dust to the optical properties observed was estimated to vary from $12-40 \%$, with a quite important sulfate contribution from anthropogenic haze of 32-60\%, and OC content (15-36\%) originating from urban combustion and/or biomass burning activities (Prosmitis et al., 2004; Sillanpää et al., 2005). At the two higher layers the inferred possible contribution of dust to the optical properties observed was lower $(0-30 \%)$, as was the sulfate contribution (18-36\%). The latter, combined with the much higher OC content (52-64\%) indicates a possible mixture of higher levels of biomass burning smoke, with dust and less continental haze particles. This, along with our retrieved aerosol optical and microphysical properties, is in agreement with Raman lidar and in situ observations reported from DABEX (Heese and Wiegner, 2008) and from SAMUM-2 in Cape Verde by Ansmann et al. (2011) and Tesche et al. (2011a) for mixture of dust and smoke particles. Furthermore, in situ airborne 
aerosol sampling together with multi-wavelength Raman lidar measurements should be performed to further evaluate the procedure proposed in this study.

Acknowledgements. The financial support for EARLINET (EARLINET-ASOS) by the European Commission under grant RICA-025991 and the European Space Agency (ESA-AO/1$5502 / 07 / \mathrm{NL} / \mathrm{HE}$ ) are gratefully acknowledged. The forecast of the dust transport model BSC-DREAM was provided by the Barcelona Supercomputing Center. Air masses back trajectories were produced with the Hybrid Single-Particle Lagrangian Integrated Trajectory model (NOAA). The authors gratefully acknowledge the NOAA Air Resources Laboratory (ARL) for the provision of the HYSPLIT transport and dispersion model. AN acknowledges support from NASA-ACMAP grant NNX08AK50G. This research has been co-financed by the European Union (European Social Fund - ESF) and Greek national funds through the Operational Program "Education and Lifelong Learning" of the National Strategic Reference Framework (NSRF) - Research Funding Program: Heracleitus II. Investing in knowledge society through the European Social Fund. Publication costs were supported by NASA-ACMAP. REM acknowledges the funding of the "Greek State Scholarship Foundation: IKY". PK acknowledges the ESA financial support under ESTEC contract 21487/08/NL/HE. The reviewers are gratefully acknowledged for their valuable comments and corrections.

Edited by: N. Mihalopoulos

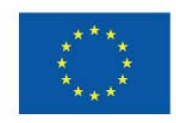

European Union Social Fund $C_{0}$ - financed by Greece and the European Union

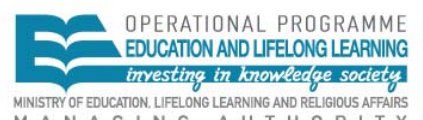

MINISTRY OF EDUCATION. LFELONG LEARNING AND RELGIOUS AFFAIRS
M A N A G I N G A U T H O R I Y Y

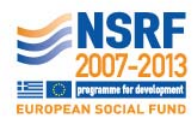

Burrows, J. P., and Mihalopoulos, N.: Impact of the 2009 Attica wild fires on the air quality in urban Athens, Atmos. Environ., 46, 536-544, 2012.

Andreae, M. O.: Climatic effects of changing atmospheric aerosol levels, in World Survey of Climatology, 16, Future Climate of the World, edited by: Henderson-Sellers, A., 341-392, Elsevier, Amsterdam, 1995.

Ansmann A., Riebesell, M., Wandinger, U., Weitkamp, C., Voss, C., Lahmann, W., and Michaelis, W.: Combined Raman Elasticbackscatter lidar for vertical profiling of moisture, aerosol extinction, backscatter, and lidar ratio, Appl. Phys., B55, 18-28, 1992.

Ansmann, A., Wagner, F., Althausen, D., Müller, D., Herber, A., and Wandinger, U.: European pollution outbreaks during ACE 2: Lofted aerosol plumes observed with Raman lidar at the Portuguese Coast, J. Geophys. Res., 106, 20725-20734, 2001.

Ansmann, A., Wagner, F., Althausen, D., Müller, D., Herber, A., Von Hoyningen-Huene, W., and Wandinger, U.: European pollution outbreaks during ACE 2: Optical particle properties from multiwavelength lidar and star/Sun photometry, J. Geophys. Res., 107, 4259, doi:10.1029/2001JD001109, 2002.

Ansmann, A., Bösenberg, J., Chaikovsky, A., Comerón, A., Eckhardt, S., Eixmann, R., Freudenthaler, V., Ginoux, P., Komguem, L., Linné, H., López Márquez, M. A., Matthias, V., Mattis, I., Mitev, V., Müller, D., Music, S., Nickovic, S., Pelon, J., Sauvage, L., Sobolewsky, P., Srivastava, M. K., Stohl, A., Torres, O., Vaughan, G., Wandinger, U., and Wiegner, M.: Long-range transport of Saharan dust to northern Europe: The 11-16 October 2001 outbreak observed with EARLINET, J. Geophys. Res., 108, 4783, doi:10.1029/2003JD003757, 2003.

Ansmann, A., Mattis, I., Müller, D., Wandinger, U., Radlach, M., and Althausen, D.: Ice formation in Saharan dust over central Europe observed with temperature/humidity/aerosol Raman lidar, J. Geophys. Res., 110, D18S12, doi:10.1029/2004JD005000, 2005.

Ansmann, A., Baars, H., Tesche, M., Müller, D., Althausen, D. Engelmann, R., Pauliquevis, T., and Artaxo, P.: Dust and smoke transport from Africa to South America: lidar profiling over Cape Verde and the Amazon rainforest, Geophys. Res. Lett. 36, L11802, doi:10.1029/2009GL037923, 2009.

\section{References}

Adams, P. J. and Seinfeld, J. H.: Predicting global aerosol size distributions in general circulation models, J. Geophys. Res., 104, 13791-13823, doi:10.1029/2001JD001010, 2002.

Amiridis, V., Kafatos, M., Pérez, C., Kazadzis, S., Gerasopoulos, E., Mamouri, R. E., Papayannis, A., Kokkalis, P., Giannakaki, E., Basart, S., Daglis, I., and Zerefos, C.: The potential of the synergistic use of passive and active remote sensing measurements for the validation of a regional dust model, Ann. Geophys., 27, 3155-3164, doi:10.5194/angeo-27-3155-2009, 2009a.

Amiridis, V., Balis, D. S., Giannakaki, E., Stohl, A., Kazadzis, S., Koukouli, M. E., and Zanis, P.: Optical characteristics of biomass burning aerosols over Southeastern Europe determined from UVRaman lidar measurements, Atmos. Chem. Phys., 9, 2431-2440, doi:10.5194/acp-9-2431-2009, 2009b.

Amiridis, V., Zerefos, C., Kazadzis, S., Gerasopoulos, E., Eleftheratos, K., Vrekoussis, M., Stohl, A., Mamouri, R. E., Kokkalis, P., Papayannis, A., Eleftheriadis, K., Diapouli, E., Keramitsoglou, I., Kontoes, C., Kotroni, V., Lagouvardos, K., Marinou, E., Giannakaki, E., Kostopoulou, E., Giannakopoulos, C., Richter, A.,
Ansmann, A., Petzold, A., Kandler, K., Tegen, I., Wendisch, M., Müller, D., Weinzierl, B., Müller, T., Heintzenberg, J.: Saharan mineral dust experiments SAMUM-1 and SAMUM-2: what have we learned?, Tellus, 63B, 403-429, 2011.

Avila, A., Queralt-Mitjans, I., and Alarcon, M.: Mineralogical composition of African dust delivered by red rains over northeastern Spain, J. Geophys. Res., 108, 21977-21996, 1997.

Balis, D., Amiridis, V., Zerefos, C., Gerasopoulos, E., Andreae, M., Zanis, P., Kazantzidis, A., Kazadzis, S., and Papayannis, A.: Raman lidar and sun-photometric measurements of aerosol optical properties over Thessaloniki during a biomass burning episode, Atmos. Environ., 37, 4529-4538, 2003.

Balis, D. S., Amiridis, V., Nickovic, S., Papayannis, A., and Zerefos, C.: Optical properties of Saharan dust layers as detected by a Raman lidar at Thessaloniki, Greece, Geophys. Res. Lett., 31, L13104, doi:10.1029/2004GL019881, 2004.

Balis, D., Amiridis, V., Kazadzis, S., Papayannis, A., Tsaknakis, G., Tzortzakis, S., Kalivitis, N., Vrekoussis, M., Kanakidou, M., Mihalopoulos, N., Chourdakis, G., Nickovic, S., Pérez, C., 
Baldasano, J., and Drakakis, M.: Optical characteristics of desert dust over the East Mediterranean during summer: a case study, Ann. Geophys., 24, 807-821, doi:10.5194/angeo-24-807-2006, 2006.

Balkanski, Y., Schulz, M., Claquin, T., and Guibert, S.: Reevaluation of Mineral aerosol radiative forcings suggests a better agreement with satellite and AERONET data, Atmos. Chem. Phys., 7, 81-95, doi:10.5194/acp-7-81-2007, 2007.

Basart, S., Pérez, C., Cuevas, E., Baldasano, J. M., and Gobbi, G. P.: Aerosol characterization in Northern Africa, Northeastern Atlantic, Mediterranean Basin and Middle East from direct-sun AERONET observations, Atmos. Chem. Phys., 9, 8265-8282, doi:10.5194/acp-9-8265-2009, 2009.

Berthier, S., Chazette, P., Couvert, P., Pelon, J., Dulac, F., Thieuleux, F., Moulin, C., and Pain, T.: Desert dust aerosol columnar properties over ocean and continental Africa from Lidar in-Space Technology Experiment (LITE) and Meteosat synergy, J. Geophys. Res., 111, D21202, doi:10.1029/2005JD006999, 2006.

Bierwirth, E., Wendisch, M., Ehrlich, A., Heese, B., Tesche, M., Althausen, D., Schladitz, A., Müller, D., Otto, S., Trautmann, T., Dinter, T., von Hoyningen, W., and Kahn, R.: Spectral surface albedo over Morocco and its impact on the radiative forcing of Saharan dust, Tellus 61B, 252-269, doi:10.1111/j.16000889.2008.00395.x, 2009.

Blanco, A., Dee Tomasi, F., Filippo, E., Manno, D., Perrone, M. R., Serra, A., Tafuro, A. M., and Tepore, A.: Characterization of African dust over southern Italy, Atmos. Chem. Phys., 3, $2147-$ 2159, doi:10.5194/acp-3-2147-2003, 2003.

Bösenberg, J., Matthias, V., Amodeo, A., Amoiridis, V., Ansmann, A., Baldasano, J. M., Balin, I., Balis, D., Böckmann, C., Boselli, A., Carlsson, G., Chaikovsky, A., Chourdakis, G., Comerón, A., De Tomasi, F., Eixmann, R., Freudenthaler, V., Giehl, H., Grigorov, I., Hågörd, A., Iarlori, M., Kirsche, A., Kolarov, G., Komguem, L., Kreipl, S., Kumpf, W., Larchevêque, G., Linné , H., Matthey, R., Mattis, I., Mekler, A., Mironova, I., Mitev, V., Mona, L., Müller, D., Music, S., Nickovic, S., Pandolfi, M., Papayannis, A., Pappalardo, G., Pelon, J., Péerez, C., Perrone, R. M., Persson, R., Resendes, D. P., Rizi, V., Rocadenbosch, F., Rodrigues, J. A., Sauvage, L., Schneidenbach, L., Schumacher, R., Shcherbakov, V., Simeonov, V., Sobolewski, P., Spinelli, N., Stachlewska, I., Stoyanov, D., Trickl, T., Tsaknakis, G., Vaughan, G., Wandinger,U., Wang, X., Wiegner, M., Zavrtanik, M., and Zerefos, C.: EARLINET project: A European Aerosol Research Lidar Network, Max-Planck Institute (MPI), Final Report, 348, 1-250, 2003.

Burton, S. P., Ferrare, R. A., Hostetler, C. A., Hair, J. W., Rogers, R. R., Obland, M. D., Butler, C. F., Cook, A. L., Harper, D. B., and Froyd, K. D.: Aerosol classification using airborne High Spectral Resolution Lidar measurements - methodology and examples, Atmos. Meas. Tech., 5, 73-98, doi:10.5194/amt-5-73-2012, 2012.

Carboni, E., Thomas, G. E., Sayer, A. M., Siddans, R., Poulsen, C. A., Grainger, R. G., Ahn, C., Antoine, D., Bevan, S., Braak, R., Brindley, H., DeSouza-Machado, S., Deuzé, J. L., Diner, D., Ducos, F., Grey, W., Hsu, C., Kalashnikova, O. V., Kahn, R., North, P. R. J., Salustro, C., Smith, A., Tanré, D., Torres, O., and Veihelmann, B.: Desert dust satellite retrieval intercomparison, Atmos. Meas. Tech. Discuss., 5, 691-746, doi:10.5194/amtd-5-
691-2012, 2012.

Chen, G., Ziemba, L. D., Chu, D. A., Thornhill, K. L., Schuster, G. L., Winstead, E. L., Diskin, G. S., Ferrare, R. A., Burton, S. P., Ismail, S., Kooi, S. A., Omar, A. H., Slusher, D. L., Kleb, M. M., Reid, J. S., Twohy, C. H., Zhang, H., and Anderson, B. E.: Observations of Saharan dust microphysical and optical properties from the Eastern Atlantic during NAMMA airborne field campaign, Atmos. Chem. Phys., 11, 723-740, 2011.

Chu, D. A., Kaufman, Y. J., Zibordi, G., Chern, J. D., Mao, J., Li, C., and Holben, B. N.: Global monitoring of air pollution over land from the Earth Observing System-Terra Moderate Resolution Imaging Spectroradiometer (MODIS), J. Geophys. Res., 108, 4661, doi:10.1029/2002JD003179, 2003.

Coude-Gaussen, G., Rognon, P., Bergametti, G., Gomez, L., Strauss, B., Gros, J.M., Le Costumer, N.: Saharan dust over Fuerteventura island (Canaries): chemical and mineralogical characteristics, air mass trajectories, and probable sources, J. Geophys.Res., 92, 9753-9771, 1987.

Coz, E., Gomez-Moreno, F.J., Pujadas, M., Casuccio G. S., Lersh, T. L., and Artinao, B.: Individual particle characteristics of North African dust under different long-transport scenarios, Atmos. Environ., 43, 1850-1863, 2009.

Cuesta J., Edouart, D., Mimouni, M., Flamant, P. H., Loth, C., Gibert, F., Marnas, F., Bouklila, A., Kharef, M., Ouchène, B., Kadi, M., and Flamant, C.: Multiplatform observations of the seasonal evolution of the Saharan atmospheric boundary layer in Tamanrasset, Algeria, in the framework of the African Monsoon Multidisciplinary Analysis field campaign conducted in 2006, J. Geophys. Res., 113, D00C07, doi:10.1029/2007JD009417, 2008.

Draxler, R. R., Stunder, B., Rolph, G., and Talylor, A.: Hysplit 4 User's Guide, NOAA Air Resources Laboratory, Silver Spring, MD, USA, 2009.

Dubovik, O., Sinyuk, A., Lapyonok, T., Holben, B. N., Mishenko, M., Yangm P., Eck, T. F., Volten, H., Munoz, O., Veihelmanné B., van der Zande, W. J., Leoné J.-F., Sorokin, M., and Slutsker, I.: Application of spheroid models to account for aerosol particle nonsphericity in remote sensing of desert dust, J. Geophys. Res., 111, D11208, doi:10.1029/2005JD006619, 2006.

Ebert, M., Weinbruch, S., Rausch, A., Gorzawski, G., Hoffmann, P., Wex, H., and Helas, G.: Complex refractive index of aerosols during LACE 98 as derived from the analysis of individual particles, J. Geophys. Res., 107, 8121, doi:10.1029/2000JD000195, 2002.

Ebert, M., Weinbruch, S., Hoffmann, P., Ortner, H. M., The chemical composition and complex refractive index of rural and urban influenced aerosols determined by individual particle analysis, Atmos. Environ., 38, 6531-6545, 2004.

Eck, T. F., Holben, B. N., Dubovik, O., Smirnov, A., Goulub, P., Chen, H. B., Chatenet, B., Gomes, L., Zhang, X.-Y., Tsay, S.C., Ji, Q., Giles, D., and Slutsker, I.: Columnar aerosol optical properties at AERONET sites in central eastern Asia and aerosol transport to the tropical mid-Pacific, J. Geophys. Res., 110, D06202, doi:10.1029/2004JD005274, 2005.

EN12341: Air quality. Determination of the $\mathrm{PM}_{10}$ fraction of suspended particulate matter. Reference method and field test procedure to demonstrate reference equivalence of measurement methods, ISBN:0580320782, 18 pp., 1999.

Engelmann, R., Ansmann, A., Horn, S., Seifert, P., Althausen, D., Tesche, M., Esselborn, M., Fruntke, J., Lieke, K., Freudenthaler, 
V., and Gross, S.: Doppler lidar studies of heat island effects on vertical mixing of aerosols during SAMUM-2, Tellus, 63B, 448458, doi:10.1111/j.1600-0889.2011.00552.x, 2011.

Feingold, G. and Morley, B.: Aerosol hygroscopic properties as measured by lidar and comparison with in situ measurements, J. Geophys. Res., 108, 4327, doi:10.1029/2002JD002842, 2003.

Forster, P., Ramaswamy, V., Artaxo, P., Bernsten, T., Betts, R., Fahey, D. W., Haywood, J., Lean, J., Lowe, D. C., Myhre, G., Nganga, J., Prinn, R., Raga, G., Schulz, M., and Van Dorland, R.: Changes in Atmospheric Constituents and in Radiative Forcing, in: Climate Change 2007: The Physical Science Basis. Contribution of Working Group I to the Fourth Assessment Report of the Intergovernmental Panel on Climate Change, edited by: Solomon, S., Qin, D., Manning, M., Chen, Z., Marquis, M., Averyt, K. B., Tignor, M., and Miller, H. L., Cambridge University Press, Cambridge, UK, 129-234, 2007.

Fountoukis, C. and Nenes, A.: ISORROPIA II: a computationally efficient thermodynamic equilibrium model for $\mathrm{KK}^{+}$. $\mathrm{Ca}^{2+}-\mathrm{Mg}^{2+}-\mathrm{NH}^{+4}-\mathrm{Na}^{+}-\mathrm{SO}_{2}^{-4}-\mathrm{NO}^{-3}-\mathrm{Cl}^{-}-\mathrm{H}_{2} \mathrm{O}$ aerosols, Atmos. Chem. Phys., 7, 4639-4659, doi:10.5194/acp-7-4639-2007, 2007.

Fountoukis, C., Nenes, A., Sullivan, A., Weber, R., Van Reken, T., Fischer, M., Matías, E., Moya, M., Farmer, D., and Cohen, R. C.: Thermodynamic characterization of Mexico City aerosol during MILAGRO 2006, Atmos. Chem. Phys., 9, 2141-2156, doi:10.5194/acp-9-2141-2009, 2009.

Franke, K., Ansmann, A., Müller, D., Althausen, D., Venkataraman, C., Reddy, M. S., Wagner, F., and Scheele, R.: Optical properties of the Indo-Asian haze layer over the tropical Indian Ocean, J. Geophys. Res., 108, 4059, doi:10.1029/2002JD002473, 2003.

Gasteiger, J., Wiegner, M., Groß, S., Freudenthaler, V., Toledano, C., Tesche, M., and Kandle, K.: Modelling lidar-relevant optical properties of complex mineral dust aerosols, Tellus, 63B, 725741, doi:10.1111/j.1600-0889.2011.00559.x, 2011a.

Gasteiger, J., Groß, S., Freudenthaler, V., and Wiegner, M.: Volcanic ash from Iceland over Munich: mass concentration retrieved from ground-based remote sensing measurements, Atmos. Chem. Phys., 11, 2209-2223, doi:10.5194/acp-11-22092011, 2011b.

Gerasopoulos, E., Amiridis, V., Kazadzis, S., Kokkalis, P., Eleftheratos, K., Andreae, M. O., Andreae, T. W., El-Askary, H., and Zerefos, C. S.: Three-year ground based measurements of aerosol optical depth over the Eastern Mediterranean: the urban environment of Athens, Atmos. Chem. Phys., 11, 2145-2159, doi:10.5194/acp-11-2145-2011, 2011.

Giannakaki, E., Balis, D. S., Amiridis, V., and Zerefos, C.: Optical properties of different aerosol types: seven years of combined Raman-elastic backscatter lidar measurements in Thessaloniki, Greece, Atmos. Meas. Tech., 3, 569-578, doi:10.5194/amt-3569-2010, 2010.

Gross, S., Tesche, M., Freudenthaler, V., Toledano, C., Wiegner, M., Ansmann, A., Althausen, D., and Seefeldner, M.: Characterization of Saharan dust, marine aerosols and a mixture of biomassburning aerosols and dust by means of multi-wavelength depolarization- and Raman measurements during SAMUM-2, Tellus, 63B, 706-724, doi:10.1111/j.1600-0889.2011.00556.x, 2011.

Hansell, R. A., Liou, K. N., Ou ,S. C., Tsay, S. C., Ji, Q., and Reid, J. S.: Remote sensing of mineral dust aerosol using AERI during the UAE2: A modelling and sensitivity study, J. Geophys. Res., 113, D18202, doi:10.1029/2008JD010246, 2008.

Haustein, K., Pérez, C., Baldasano, J. M., Müller, D., Tesche, M., Schladitz, A., Esselborn, M., Weinzier, B., Kandler, K., and von Hoyningen-Huene, W.: Regional dust model performance during SAMUM 2006, Geophys. Res. Lett., 36, L03812, doi:10.1029/2008GL036463, 2009.

Haywood, J. M., Allan, R. P., Culverwell, I., Slingo, T., Milton, S. Edwards, J., and Clerbeaux, N.: Can desert dust explain the outgoing longwave radiation anomaly over the Sahara during July 2003?, J. Geophys. Res., 110, D05105, doi:10.1029/2004JD005232, 2005.

Heald, C. L., Jacob, D. J., Park, R. J., Russell, L. M., Huebert, B., J., Seinfeld, J. H., Liao, H., and Weber, R. J.: A large organic aerosol source in the free troposphere missing from current models, J. Geophys. Res. 32, L18809, doi:10.1029/2005GL023831, 2005.

Heese, B. and Wiegner, M.: Vertical aerosol profiles from Raman polarization lidar observations during the dry season AMMA field campaign, J. Geophys. Res. 113, D00C11, doi:10.1029/2007JD009487, 2008.

Heinold, B., Helmert, J., Hellmuth, O., Wolke, R., Ansmann, A., Marticorena, B., Laurent, B., and Tegen, I.: Regional modeling of Saharan dust events using LM-MUSCAT: Model description and case studies, J. Geophys. Res., 112, D11204, doi:10.1029/2006JD007443, 2007.

Holben, B. N., Eck, T. F., Slutsker, I., Tanré, D., Buis, J. P., Setzer, A., Vermote, E., Reagan, J. A., Kaufman, Y. J., Nakajima, T., Lavenu, F., Jankowiak, I., and Smirnov, A.: AERONET-A federated instrument network and data archive for aerosol characterization, Rem. Sens. Environ., 66, 1-16, doi:10.1016/S00344257(98)00031-5, 1998.

Holben, B. N., Eck, T. F., Slutsker, I., Smirnov, A., Sinyuk, A., Schafer, J., Giles, D., and Dubovik, O.: AERONET's version 2.0 quality assurance criteria, Proc. SPIE, 6408, 64080Q, doi.org/10.1117/12.706524, 2006.

Jiménez-Guerrero, P., Pérez, C., Jobra, O., and Baldasano, J.: Contribution of Saharan dust in 15 an ingrated air quality system and its on-line assessment, Geophys. Res. Lett., 35, L03814, doi:10.1029/2007GL031580, 2008.

Kandler, K., Schütz, L., Deutscher, C., Hofmann, H., Jäckel, S., Knippertz, P., Lieke, K., Maßling, A., Schladitz, A., Weinzierl, B., Zorn, S., Ebert, M., Jaenicke, R., Petzold, A., Weinbruch, S.: Size distribution, mass concentration, chemical and mineralogical composition, and derived optical parameters of the boundary layer aerosol at Tinfou, Morocco, during SAMUM 2006, Tellus, 61B, 32-50, 2009.

Karageorgos, E. T. and Rapsomanikis, S.: Chemical characterization of the inorganic fraction of aerosols and mechanisms of the neutralization of atmospheric acidity in Athens, Greece, Atmos. Chem. Phys., 7, 3015-3033, doi:10.5194/acp-7-3015-2007, 2007.

Karydis, V. A., Tsimpidi, A. P., Fountoukis, C., Nenes, A., Zavala, M., Lei, W., Molina, L. T., and Pandis, S. N.: Simulating the fine and coarse inorganic particulate matter concentrations in a polluted megacity, Atmos. Environ., 44, 608-620, 2010.

Kaufman, Y. and Tanré, D.: Algorithms for remote sensing of tropospheric aerosol from MODIS. NASA MODIS Algorithm Theoretical Basis Document, Goddard Space Flight Center, 85 pp., 
1998.

Kim, K. W., He, Z., and Kim, Y. J.: Physicochemical characteristics and radiative properties of Asian dust particles observed at Kwangju, Korea, during the 2001 ACE-Asia intensive observation period, J. Geophys. Res., 109, D19S02, doi:10.1029/2003JD003693, 2004.

Kim, H.-S., Chung, Y. -C., and Lee, S. G.: Analysis of spatial and seasonal distributions of MODIS aerosol optical properties and ground-based measurements of mass concentrations in the Yellow Sea region in 2009, Environ Monit. Assess., 1973-1984, doi:10.1007/s10661-012-2559, 2012.

Kinne, S., Schulz, M., Textor, C., Guibert, S., Balkanski, Y., Bauer, S. E., Berntsen, T., Berglen, T. F., Boucher, O., Chin, M., Collins, W., Dentener, F., Diehl, T., Easter, R., Feichter, J., Fillmore, D., Ghan, S., Ginoux, P., Gong, S., Grini, A., Hendricks, J., Herzog, M., Horowitz, L., Isaksen, I., Iversen, T., Kirkevåg, A., Kloster, S., Koch, D., Kristjansson, J. E., Krol, M., Lauer, A., Lamarque, J. F., Lesins, G., Liu, X., Lohmann, U., Montanaro, V., Myhre, G., Penner, J., Pitari, G., Reddy, S., Seland, O., Stier, P., Takemura, T., and Tie, X.: An AeroCom initial assessment - optical properties in aerosol component modules of global models, Atmos. Chem. Phys., 6, 1815-1834, doi:10.5194/acp-6-1815-2006, 2006.

Kleidman, R. G., Smirnov, A., Levy, R. C., Mattoo, S., and Tanré, D.: Evaluation and wind speed dependence of MODIS aerosol retrievals over open ocean, IEEE T. Geosci. Remote, 50, 429435, 2012.

Koulouri, E., Saarikoski, S., Theodosi, C., Markaki, Z., Gerasopoulos, E., Kouvarakis, G., Mäkelä, T., Hillamo, R., and Mihalopoulos, N.: Chemical composition and sources of fine and coarse aerosol particles in the Eastern Mediterranean, Atmos. Environ., 42, 6542-6550, 2008.

Lelieveld, J., Berresheim, H., Borrmann, S., Crutzen, P. J., Dentener, F. J., Fischer, H., Feichter, J., Flatau, P. J., Heland, J., Holzinger, R., Korrmann, R., Lawrence, M. G., Levin, Z., Markowicz, K. M., Mihalopoulos, N., Minikin, A., Ramanathan, V., de Reus, M., Roelofs, G. J., Scheeren, H. A., Sciare, J., Schlager, H., Schultz, M., Siegmund, P., Steil, B., Stephanou, E., Stier, P., Traub, M., Warneke, C., Williams, J., and Ziereis, H.: Global air pollution crossroads over the Mediterranean, Science, 794-799, 2002, doi:10.1126/science.1075457.

Léon, J.-F., Tanré, D., Pelon, J., Kaufman, Y. J., Haywood, J. M., and Chatenet, B.: Profiling of a Saharan dust outbreak based on a synergy between active and passive remote sensing, J. Geophys. Res., 108, 8575, doi:10.1029/2002JD002774, 2003.

Levin, Z. and Cotton, W.: Aerosol Pollution Impact on Precipitation: A Scientific Review, Springer, New York, USA, 2009.

Levy, R. C., Remer, L. A., Mattoo, S., Vermote, E. F., and Kaufman, Y. J.: Second generation operational algorithm: Retrieval of aerosol properties over land from inversion of Moderate Resolution Imaging Spectrometer spectral reflectance, J. Geophys. Res., 112, D13211, doi:10.1029/2006JD007811, 2007.

Levy, R. C., Remer, L. A., Kleidman, R. G., Mattoo, S., Ichoku, C., Kahn, R., and Eck, T. F.: Global evaluation of the Collection 5 MODIS dark-target aerosol products over land, Atmos. Chem. Phys., 10, 10399-10420, doi:10.5194/acp-10-10399-2010, 2010.

Lieke, K., Kandler, K., Scheuvens, D., Emmel, C., Von Glahn, C., Petzold, A., Weinzierl, B., Veira, A., Ebert, M., Weinbruch, S., and Schütz, L.: Particle chemical properties in the vertical col- umn based on aircraft observations in the vicinity of Cape Verde Islands, Tellus, 63B, 497-511, 2011.

Liu, Z., Winker, D., Omar, A., Vaughan, M., Trepte, C., Hu, Y., Powell, K., Sun, W., Lin, B.: Effective lidar ratios of dense dust layers over North Africa derived from the CALIOP measurements, J. Quant. Spectrosc. Ra., 112, 204-213, 2011.

Lohmann, U., Rotstayn, L., Storelvmo, T., Jones, A., Menon, S., Quaas, J., Ekman, A. M. L., Koch, D., and Ruedy, R.: Total aerosol effect: radiative forcing or radiative flux perturbation?, Atmos. Chem. Phys., 10, 3235-3246, doi:10.5194/acp-10-32352010, 2010.

Mahowald, N. M., Yoshioka, M., Collins, W. D., Conley, A. J., Fillmore, D.W., and Coleman, D. B.: Climate response and radiative forcing from mineral aerosols during the last glacial maximum, pre-industrial, current and doubled-carbon dioxide climates, Geophys. Res. Lett., 33, L20705, doi:10.1029/2006gl026126, 2006.

Mamouri, R. E., Papayannis, A., Tsaknakis, G., Amiridis, V., and Koukouli, M.: First water vapor measurements over Athens, Greece, obtained by a combined Raman-elastic backscatter lidar system, Opt. Pura Aplic., 41, 109-116, 2008.

Mamouri, R. E., Amiridis, V., Papayannis, A., Giannakaki, E., Tsaknakis, G., and Balis, D. S.: Validation of CALIPSO spaceborne-derived aerosol vertical structures using a ground-based lidar in Athens, Greece, Atmos. Meas. Tech. Discuss., 2, 561-587, doi:10.5194/amtd-2-561-2009, 2009.

Markou, M. T. and Kassomenos, P.: Cluster analysis of five years of back trajectories arriving in Athens, Greece, Atmos. Res., 98, 438-457, 2010.

Matthias, V., Balis, D., Boesenberg, J., Eixmann, R., Iarlori, M., Komguem, L., Mattis, I., Papayannis, A., Pappalardo, G., Perrone, M. R., and Wang, X.: Vertical aerosol distribution over Europe: Statistical analysis of Raman lidar data from 10 European Aerosol Research Lidar Network (EARLINET) stations, J. Geophys. Res., 109, 1-12, 2004.

Mattis I., Müller, D., Ansmann, A., Wandinger, U., Preissler, J., Seifert, P., and Tesche, M.: Ten years of multiwavelength Raman lidar observations of free-tropospheric aerosol layers over central Europe: Geometrical properties and annual cycle, J. Geophys. Res., 113, D20202, doi:10.1029/2007JD009636, 2008.

McConnell, C. L., Highwood, E. J., Coe, H., Formenti, P., Anderson, B., Osborne, S., Nava, S., Desboeufs, K., Chen, G., and Harrison, M. A. J.: Seasonal variations of the physical and optical characteristics of Saharan dust: results from the Dust Outflow and Deposition to the Ocean (DODO) experiment, J. Geophys. Res., 113, D14S05, doi:10.1029/2007JD009606, 2008.

McConnell, C. L., Formenti, P., Highwood, E. J., and Harrison, M. A. J.: Using aircraft measurements to determine the refractive index of Saharan dust during the DODO Experiments, Atmos. Chem. Phys., 10, 3081-3098, doi:10.5194/acp-10-3081-2010, 2010.

Merikallio, S., Lindqvist, H., Nousiainen, T., and Kahnert, M.: Modelling light scattering by mineral dust using spheroids: assessment of applicability, Atmos. Chem. Phys., 11, 5347-5363, doi:10.5194/acp-11-5347-2011, 2011.

Metzger, S., Mihalopoulos, N., and Lelieveld, J.: Importance of mineral cations and organics in gas-aerosol partitioning of reactive nitrogen compounds: case study based on MINOS results, Atmos. Chem. Phys. Discuss., 5, 12857-12893, 
doi:10.5194/acpd-5-12857-2005, 2005.

Min, Q.-L., Li, R., Lin, B., Joseph, E., Wang, S., Hu, Y., Morris, V., and Chang, F.: Evidence of mineral dust altering cloud microphysics and precipitation, Atmos. Chem. Phys., 9, 3223-3231, doi:10.5194/acp-9-3223-2009, 2009.

Mishchenko, M. I. and Hovenier, J. W.: Depolarization of light backscattered by randomly oriented nonspherical particles, Opt. Lett., 20, 1356-1358, 1995.

Mishchenko, M. I., Travis, L. D., Kahn, R. A., and West, R. A.: Modelling phase functions for dustlike tropospheric aerosols using a mixture of randomly oriented polydisperse spheroids, J. Geophys. Res., 102, 16831-16847, 1997.

Mishchenko, M. I., Geogdzhayev, I. V., Liu, L., Ogren, J. A., Lacis, A. A., Rossow, W. B., Hovenier, J. W., Volten, H., and Muoz, O.: Aerosol retrievals from AVHRR radiances: effects of particle nonsphericity and absorption and an updated long-term global climatology of aerosol properties, J. Quant. Spectrosc. Radiat. Transfer, 79/80, 953-972, 2003.

Misra, A., Jayaraman, A., and Ganguly, D.: Validation of MODIS derived aerosol optical depth over Western India, J. Geophys. Res., 113, D04203, doi:10.1029/2007JD009075, 2008.

Mona, L., Pappalardo, G., Amodeo, A., D’Amico, G., Madonna, F., Boselli, A., Giunta, A., Russo, F., and Cuomo, V.: One year of CNR-IMAA multi-wavelength Raman lidar measurements in coincidence with CALIPSO overpasses: Level 1 products comparison, Atmos. Chem. Phys., 9, 7213-7228, doi:10.5194/acp-97213-2009, 2009.

Moya, M., Ansari, A. S., and Pandis, S. N.: Partitioning of nitrate and ammonium between the gas and particulate phases during the 1997 IMADA-AVER study in Mexico City, Atmos. Environ., 35, 1791-1804, 2001.

Müller, D., Wandinger, U., and Ansmann, A.: Microphysical particle parameters from extinction and backscatter lidar data by inversion with regularization: theory, Appl. Opt., 38, 2346-2357, 1999.

Müller, D., Franke, K., Ansmann, A., Althausen, D., and Wagner, F.: Indo-Asian pollution during INDOEX: Microphysical particle properties and single-scattering albedo inferred from multiwavelength lidar observations, J. Geophys. Res., 108, 4600, doi:10.1029/2003JD003538, 2003.

Müller, D., Mattis, I., Ansmann, A., Wehner, B., Althausen, D., Wandinger, U., and Dubovik, O.: Closure study on optical and microphysical properties of a mixed urban and Arctic haze air mass observed with Raman lidar and Sun photometer, J. Geophys. Res., 109, D13206, doi:10.1029/2003JD004200, 2004.

Müller, D., Mattis, I., Wandinger, U., Ansmann, A., Althausen, D., and Stohl, A.: Raman lidar observations of aged Siberian and Canadian forest-fire smoke in the free troposphere over Germany in 2003: microphysical particle characterization, J. Geophys. Res., 110, D17201, doi:10.1029/2004JD005756, 2005.

Müller, D., Ansmann, A., Mattis, I., Tesche, M., Wandinger, U., Altahusen, D., and Pisdani, G.: Aerosol-type-dependent lidar ratios observed with Raman lidar, J. Geophys. Res., 111, D16202, doi:10.1029/2006JD008292, 2007.

Müller, D., Heinold, B., Tesche, M., Tegen, I., Althausen, D., Amiridis, V., Amodeo, A., Ansmann, A., Alados-Arboledas, L. Balis, D., Comeron, A., D’Amico, G., Gerasopoulos, E., Freudenthaler, V., Giannakaki, E., Heese, B., Iarlori, M., Mamouri, R. E., Mona, L., Papayannis, A., Pappalardo, G.,
Perrone, R.-M., Pisani, G., Rizi, V., Sicard, M., Spinelli, N., Tafuro, A.: EARLINET Observations of the 14-22 May LongDust Transport Event During SAMUM 2006: Validation Results From Dust Transport Modelling, Tellus, 61B, 325-339, 2009.

Müller, D., Weinzierl, B., Petzold, A., Kandler, K., Ansmann, A., Müller, T., Tesche, M., Freudenthaler, V., Esselborn, M., Heese, B., Althausen, D., Schladitz, A., Otto, S., and Knippertz. P.: Mineral dust observed with AERONET Sun-sky radiometer, Raman lidar, and in situ instruments during SAMUM 2006: Shapeindependent particle properties, J. Geophys. Res., 115, D07202, doi:10.1029/2009JD012520, 2010.

Müller, T., Schladitz, A., Massling, A., Kaaden, A., Kandler, K., and Wiedensohler, A.: Spectral absorption coefficients and imaginary parts of refractive indices of Saharan dust during SAMUM1, Tellus, 61B, 79-95, 2009.

Müller, T., Schladitz, A., Kandler, K., and Wiedensohler, A.: Spectral particle absorption coefficients, single scattering albedos, and imaginary parts of refractive indices from ground based insitu measurements at Cape Verde Island during SAMUM-2, Tellus, 63B, 573-588, 2011.

Nickovic, Kallos, G., Papadopoulos, A., and Kakaliagou, O.: A model for prediction of desert dust cycle in the atmosphere, J. Geophys. Res., 106, 18113-18129, 2001.

Noh, Y. M., Kim, Y. J., Choi, B. C., and Murayama, T.: Aerosol lidar ratio characteristics measured by a multi-wavelength Raman lidar system at Anmyeon island, Korea, Atmos. Res., 86, 76-87, doi:10.1016/j.atmosres.2007.03.006, 2007.

Noh, Y. M., Müller, D., Shin, D. H., Lee, H., Jung, J. S., Lee, K. H., Cribb, M., Li, Z., and Kim, Y. J.:, Optical and microphysical properties of severe haze and smoke aerosol measured by integrated remote sensing techniques in Gwangju, Korea, Atmos. Environ., 43, 879-888, 2009.

Nowak, J. B., Huey, L. G., Russell, A. G., Tian, D., Neuman, J. A., Orsini, D., Sjostedt, S. J., Sullivan, A. P., Tanner, D. J., Weber, R. J., Nenes, A., Edgerton, E., and Fehsenfeld, F. C.: Analysis of urban gas phase ammonia measurements from the 2002 Atlanta Aerosol Nucleation and Real-Time Characterization Experiment (ANARChE), J. Geophys. Res., 111, D17308, doi:10.1029/2006JD007113, 2006.

Osterloch, L., Böckmann, C., Mamouri, R. E., Papayannis, A.: An adaptive base point algorithm for the retrieval of aerosol microphysical properties, The Open Atmospheric Science Journal, 5, 61-73, 2011.

Otto, S., Bierwirth, E., Weinzierl, B., Kandler, K., Esselborn, M., Tesche, M., Schladitz, A.,Wendisch, M., and Trautmann, T.: Solar radiative effects of a Saharan dust plume observed during SAMUM assuming spheroidal model particles, Tellus, 61B, 270296, 2009.

Pahlow, M., Müller, D., Tesche, M., Eichler, H., Feingold, G., Eberhard, W. L., and Cheng, Y.-F.: Retrieval of aerosol properties from combined multiwavelength lidar and sunphotometer measurements, Appl. Opt., 45, 7429-7442, 2006.

Papadimas, C. D., Hatzianastassiou, N., Mihalopoulos, N., Kanakidou, M., Katsoulis, B. D., and Vardavas, I.: Assessment of the MODIS Collections C005 and C004 aerosol optical depth products over the Mediterranean basin, Atmos. Chem. Phys., 9, 2987-2999, doi:10.5194/acp-9-2987-2009, 2009.

Papayannis, A., Balis, D., Amiridis, V., Chourdakis, G., Tsaknakis, G., Zerefos, C., Castanho, A. D. A., Nickovic, S., Kazadzis, 
S., and Grabowski, J.: Measurements of Saharan dust aerosols over the eastern Mediterranean using elastic backscatter-Raman lidar, spectrophotometric and satellite observations in the frame of the EARLINET project, Atmos. Chem. Phys., 5, 2065-2079, doi:10.5194/acp-5-2065-2005, 2005.

Papayannis, A., Amiridis, V., Mona, L., Tsaknakis, G., Balis, D., Bösenberg, J., Chaikovski, A., De Tomasi, F., Grigorov, I., Mattis, I., Mitev, V., Müller, D., Nickovic, S., Perez, C., Pietruczuk, A., Pisani, G., Ravetta, F., Rizi, V., Sicard, M., Trickl, T., Wiegner, M., Gerding, M., Mamouri, R. E., D’Amico, G., and Pappalardo, G.: Systematic lidar observations of Saharan dust over Europe in the frame of EARLINET (2000-2002), J. Geophys. Res., 113, D10204, doi:10.1029/2007JD009028, 2008.

Pappalardo, G., Wandinger, U., Mona, L., Hiebsch, A., Mattis, I., Amodeo, A., Ansmann, A., Seifert, P., Linnè, H., Apituley, A., Alados Arboledas, L., Balis, D., Chaikovsky, A., Comeron, A., D’Amico, G., Freudenthaler, V., Grigorov, I., Papayannis, A., Perrone, M. R., Pietruczuk, A., Pujadas, M., Rizi, V., Spinelli, N., Wang, X., Wiegner, M.: EARLINET correlative measurements for CALIPSO: first intercomparison results, J. Geophys. Res., 115, D00H19, doi:10.1029/2009JD012147, 2010.

Patterson, E. M., Filette, D. A., and Stockton, B. H.: Complex index of refraction between 300 and $700 \mathrm{~nm}$ for Saharan aerosols, J. Geophys. Res., 82, 3153-3160, 1977.

Pay, M. T., Piot, M., Jorba, O., Gassó, S., Gonçalves, M., Basart, S., Dabdub, D., Jiménez-Guerrero, P., Baldasano, J. M.: A full year evaluation of the CALIOPE-EU air quality modelling system over Europe for 2004, Atmos. Environ., 44, 3322-3342, 2010.

Pelon, J., Mallet, M., Mariscal, A., Goloub, G., Tanré, D. Bou Karam, D., Flamant, C., Haywood, J., Pospichal, B., and Victori, S.: Microlidar observations of biomass burning aerosol over Djougou (Benin) during African Monsoon Multidisciplinary Analysis Special Observation Period 0: Dust and Biomass-Burning Experiment, J. Geophys. Res. 113, D00C18, doi:10.1029/2008JD009976, 2008.

Pérez, C., Nickovic, S., Baldasano, J. M., Sicard, M., Rocadenbosch, F., and Cachorro, V. E.: A long Saharan dust event over the western Mediterranean: Lidar, Sun photometer observations, and regional dust modelling, J. Geophys. Res., 111, D15214, doi:10.1029/2005JD006579, 2006a.

Pérez, C., Nickovic, S., Pejanovic, G., Baldasano, J. M., and Ozsoy, E.: Interactive dustradiation modelling: A step to improve weather forecasts, J. Geophys. Res., 111, D16206, doi:10.1029/2005JD006717, 2006b.

Petzold, A., Rasp, K., Weinzierl, B., Esselborn, M., Hamburger, T., Dornbrack, Kandler, K., Schutz, L., Knippertz, P., Fiebig, M., and Virkkula, A.: Saharan dust absorption and refractive index from aircraft-based observations during SAMUM 2006, Tellus, 61B, 118-130, 2009.

Pikridas, M., Bougiatioti, A., Hildebrandt, L., Engelhart, G. J., Kostenidou, E., Mohr, C., Prévót, A. S. H., Kouvarakis, G., Zarmpas, P., Burkhart, J. F., Lee, B.-H., Psichoudaki, M., Mihalopoulos, N., Pilinis, C., Stohl, A., Baltensperger, U., Kulmala, M., and Pandis, S. N.: The Finokalia Aerosol Measurement Experiment - 2008 (FAME-08): an overview, Atmos. Chem. Phys., 10, 6793-6806, doi:10.5194/acp-10-6793-2010, 2010.

Prasad, A. K. and Singh, R. P.: Validation of MODIS Terra, AIRS, NCEP/DOE AMIP-II Reanalysis-2, and AERONET Sun photometer derived integrated precipitable water vapor using ground-based GPS receivers over India, J. Geophys. Res., 114, D05107, doi:10.1029/2008JD011230, 2009.

Pringle, K. J., Tost, H., Metzger, S., Steil, B., Giannadaki, D., Nenes, A., Fountoukis, C., Stier, P., Vignati, E., and Lelieveld, J.: Corrigendum to "Description and evaluation of GMXe: a new aerosol submodel for global simulations (v1)" published in Geosci. Model Dev., 3, 391-412, 2010, Geosci. Model Dev., 3, 413-413, doi:10.5194/gmd-3-413-2010, 2010.

Prosmitis, A. B., Diapouli, E., Grivas, G., Chaloulakou, A., and Spyrellis, N.: Continuous field measurements of organic and elemental carbon concentrations in Athens, Greece, J. Aerosol Sci., 35, S1077-S1078, 2004.

Pye, H. O. T., Liao, H., Wu, S., Mickley, L. J., Jacob, D. J., Henze D. K., and Seinfeld, J. H.: Effect of changes in climate and emissions on future sulfate-nitrate-ammonium aerosol levels in the United States, J. Geophys. Res., 114, D01205, 2009.

Ramanathan, V., Crutzen, P. J., Kiehl, J. T., and Rosenfeld, D.: Aerosols, climate and the hydrological cycle, Science, 294, 2119-2123, doi:10.1126/science.1064034, 2001.

Ramanathan, V., Crutzen, P. J., Lelieveld, J., Mitra, A. P., Althausen, D., Anderson, J., Andreae, M. O., Cantrell, W., Cass, G. R., Chung, C. E., Clarke, A. D., Coakley, J. A., Collins, W. D., Conant, W. C., Dulac, F., Heintzenberg, J., Heymsfield, A. J., Holben, B., Howell, S., Hudson, J., Jayaraman, A., Kiehl, J. T., Krishnamurti, T. N., Lubin, D., McFarquhar, G., Novakov, T., Ogren, J. A., Podgorny, I. A., Prather, K., Priestley, K., Prospero, J. M., Quinn, P. K., Rajeev, K., Rasch, P., Rupert, S., Sadourny, R., Satheesh, S. K., Shaw, G. E., Sheridan, P., and Valero, F. P. J.: Indian Ocean experiment: an integrated analysis of the climate forcing and effects of the great Indo-Asian haze, J. Geophys. Res., 106, 28371-28398, 2001.

Ramanathan, V. and Feng, Y.: Air pollution, greenhouse gases and climate change: Global and regional perspectives, Atmos. Environ., 43, 37-50, 2009.

Raut, J.-C. and Chazette, P.: Vertical profiles of urban aerosol complex refractive index in the frame of ESQUIF airborne measurements, Atmos. Chem. Phys., 8, 901-919, doi:10.5194/acp8-901-2008, 2008.

Redemann, J., Vaughan, M. A., Zhang, Q., Shinozuka, Y., Russell, P. B., Livingston, J. M., Kacenelenbogen, M., and Remer, L. A.: The comparison of MODIS-Aqua (C5) and CALIOP (V2 \& V3) aerosol optical depth, Atmos. Chem. Phys., 12, 3025-3043, doi:10.5194/acp-12-3025-2012, 2012.

Reid, J. S., Kinney, J. E., Westphal, D. L., Holben, B. N., Welton, E. J., Tsay, S. C., Eleuterio, D. P., Campbell, J., Christopher, S. A., Jonsson, H. H., Livingston, J. M., Maring, H. B., Meier, M. M., Pilewskie, P., Prospero, J., Reid, E. A., Remer, L. A., Russell, P. B., Savoie, D. L., Smirnov, A. A., and Tanré, D.: Analysis of measurements of Saharan dust by airborne and ground-based remote sensing methods during the Puerto Rico Dust Experiment (PRIDE), J. Geophys. Res. 108, 8586, doi:10.1029/2002JD002493, 2003.

Remer, L. A., Kaufman, Y. J., Tanré, D., Mattoo, S., Chu, D. A.,Martins, J. V., Li, R.-R., Cichoku, C., Levy, R. C., Kleidman, R. G., Eck, T. F., Vermote, E., and Holben, B. N.: The MODIS Aerosol Algorithm, Products, and Validation, J. Atmos. Sci., 62, 947-973, 2005.

Remer, L. A., Kleidman, R. G., Levy, R. C., Kaufman, Y. J., Tanré, D., Mattoo, S., Martins, J. V., Ichoku, C., Koren, I., 
Yu, H. B., Holben, B. N.: Global aerosol climatology from the MODIS satellite sensors, J. Geophys. Res., 113, D14S07, doi:10.1029/2007JD009661, 2008.

Remoundaki, E., Bourliva, A., Kokkalis, Mamouri, R.E., P., Papayannis, A., Grigoratos, T., Samara, C., and Tsezos, M.: Composition of $\mathrm{PM}_{10}$ during a Saharan dust transport event over Athens, Greece, Sci. Total Environ., 409, 4361-4372, doi:10.1016/j.scitotenv.2011.06.026, , 2011.

Ridley, D. A., Heald, C. L., and Ford, B.: North African dust export and deposition: A satellite and model perspective, J. Geophys. Res., 117, D02202, doi:10.1029/2011JD016794, 2012.

Rodríguez, S., Alastuey, A., Alonso-Pérez, S., Querol, X., Cuevas, E., Abreu-Afonso, J., Viana, M., Pérez, N., Pandolfi, M., and de la Rosa, J.: Transport of desert dust mixed with North African industrial pollutants in the subtropical Saharan Air Layer, Atmos. Chem. Phys., 11, 6663-6685, doi:10.5194/acp-11-66632011, 2011.

Russell, P. B., Livingston, J. M., Redemann, J., Schmid, B., Ramirez, S. A., Eilers, J., Kahn, R., Chu, A., Remer, L., Quinn, P. K., Rood, M. J., and Wang, W.: Multi-gridcell validation of satellite aerosol property retrievals in INTEX/ITCT/ICARTT 2004, J. Geophys. Res., 112, D12S09, doi:10.1029/2006JD007606, 2007.

San Martini, F. M., Dunlea, E. J., Volkamer, R., Onasch, T. B., Jayne, J. T., Canagaratna, M. R., Worsnop, D. R., Kolb, C. E., Shorter, J. H., Herndon, S. C., Zahniser, M. S., Salcedo, D., Dzepina, K., Jimenez, J. L., Ortega, J. M., Johnson, K. S., McRae, G. J., Molina, L. T., and Molina, M. J.: Implementation of a Markov Chain Monte Carlo method to inorganic aerosol modelling of observations from the MCMA-2003 campaign Part II: Model application to the CENICA, Pedregal and Santa Ana sites, Atmos. Chem. Phys., 6, 4889-4904, doi:10.5194/acp6-4889-2006, 2006.

Santese, M., De Tomasi, F., and Perrone, M. R.: Advection patterns and aerosol optical and microphysical properties by AERONET over south-east Italy in the central Mediterranean, Atmos. Chem. Phys., 8, 1881-1896, doi:10.5194/acp-8-1881-2008, 2008.

Satheesh, S. K. and Moorthy, K. K.: Radiative effects of natural aerosols: A review, Atmos. Environ., 39, 2089-2110, doi:10.1016/j.atmosenv.2004.12.029, 2005.

Sciare, J., Bardouki, H., Moulin, C., and Mihalopoulos, N.: Aerosol sources and their contribution to the chemical composition of aerosols in the Eastern Mediterranean Sea during summertime, Atmos. Chem. Phys., 3, 291-302, doi:10.5194/acp-3-291-2003, 2003.

Sciare, J., Oikonomou, K., Favez, O., Liakakou, E., Markaki, Z., Cachier, H., and Mihalopoulos, N.: Long-term measurements of carbonaceous aerosols in the Eastern Mediterranean: evidence of long-range transport of biomass burning, Atmos. Chem. Phys., 8 , 5551-5563, doi:10.5194/acp-8-5551-2008, 2008.

Seinfeld, J. H. and Pandis, S.: Atmospheric Chemistry and Physics - From Air Pollution to Climate Change (2nd Edn.), John Wiley \& Sons, 2006.

Sicard, M., Rocadenbosch, F., Reba, M. N. M., Comerón, A., Tomás, S., García-Vízcaino, D., Batet, O., Barrios, R., Kumar, D., and Baldasano, J. M.: Seasonal variability of aerosol optical properties observed by means of a Raman lidar at an EARLINET site over Northeastern Spain, Atmos. Chem. Phys., 11, 175-190, doi:10.5194/acp-11-175-2011, 2011.
Sillanpää, M., Frey, A., Hillamo, R., Pennanen, A. S., and Salonen, R. O.: Organic, elemental and inorganic carbon in particulate matter of six urban environments in Europe, Atmos. Chem. Phys., 5, 2869-2879, doi:10.5194/acp-5-2869-2005, 2005.

Smirnov, A., Holben, B. N., Eck, T. F., Dubovik, O., Slutsker, I.: Cloud-screening and quality control algorithms for the AERONET database, Rem. Sens. Environ., 73, 337-349, 2000.

Sokolik, I. N. and Toon, O. B.: Incorporation of mineralogical composition into models of the radiative properties of mineral aerosol from UV to IR wavelengths, J. Geophys. Res., 104, 9423-9444, 1999.

Sokolik, I. N., Andronova, A., and Johnson, T. C.: Complex refractive index of atmospheric dust aerosols, Atmos. Environ., 27A, 16, 2495-2502, 1993.

Sokolik, I. N., Winker, D. M., Bergametti, G., Gillette, D. A., Carmichael, G., Kaufman, Y. J., Gomes, L., Schütz, L., and Penner, J. E.: Introduction to special section: outstanding problems in quantifying the radiative impacts of mineral dust, J. Geophys. Res., 106, 18015-18027, 2001.

Sugimoto, N., Uno, I., Nishikawa, M., Shimizu, A., Matsui, I., Dong, X., Chen, Y., and Quan, H.: Record heavy Asian dust in Beijing in 2002: Observations and model analysis of recent events, Geophys. Res. Lett., 30, 1640, doi:10.1029/2002GL016349, 2003.

Tanré, D., Kaufman, Y. J., Herman, M., and Mattoo, S.: Remote sensing of aerosol properties over oceans using the MODIS/ESO spectral radiances, J. Geophys. Res., 102, 16971-16988, 1997.

Terzi, E., Argyropoulos, G., Bougatioti, A., Mihalopoulos, N., Nikolaou, K., and Samara C.: Chemical composition and mass closure of ambient $\mathrm{PM}_{10}$ at urban sites, Atmos. Environ., 44, 2231-2239, 2010.

Tesche, M., Ansmann, A., Müller, D., Althausen, D., Engelmann, R., Freudenthaler, V., and Groß, S.: Vertically resolved separation of dust and smoke over Cape Verde using multiwavelength Raman and polarization lidars during Saharan Mineral Dust Experiment 2008, J. Geophys. Res., 114, D13202, doi:10.1029/2009JD011862, 2009a.

Tesche, M., Ansmann, A., Müller, D., Althausen, D., Mattis, I. Heese, B., Freudenthaler, V., Wiegner, M., Esselborn, M., Pisani, G., and Knippertz, P.: Vertical profiling of Saharan dust with Raman lidars and airborne HSRL in southern Morocco during SAMUM, Tellus, 61B, 144-164, doi:j.1600-0889.2008.00390.x, 2009b.

Tesche, M., Groß, S., Ansmann, A., Müller, D., Althausen, D., Freudenthaler, V., Esselborn, M.: Profiling of Saharan dust and biomass-burning smoke with multi-wavelength polarization Raman lidar at Cape Verde, Tellus, 63B, 649-676, doi:10.1111/j.1600-0889.2011.00548.x 2011a.

Tesche, M., Müller, D., Groß, S., Ansmann, A., Althausen, D., Freudenthaler, V., Weinzierl, B., Veira, A., and Petzold, A.: Optical and microphysical properties of smoke over Cape Verde inferred from multiwavelength lidar measurements, Tellus, 63B, 677-694, doi:10.1111/j.1600-0889.2011.00549.x 2011b.

Theodosi, C., Grivas, G., Zarmpas, P., Chaloulakou, A., and Mihalopoulos, N.: Mass and chemical composition of sizesegregated aerosols $\left(\mathrm{PM}_{1}, \mathrm{PM}_{2.5}, \mathrm{PM}_{10}\right)$ over Athens, Greece: local versus regional sources, Atmos. Chem. Phys., 11, 1189511911, doi:10.5194/acp-11-11895-2011, 2011. 
Veselovskii, I., Kolgotin, A., Griaznov, V., Müller, D., Wandinger, U., Whiteman, D. N.: Inversion with regularization for the retrieval of tropospheric aerosol parameters from multi-wavelength lidar sounding, Appl. Opt., 41, 3685-3699, 2002.

Veselovskii, I., Whiteman, D. N., Kolgotin, A., Andrews, E., Korenskii, M.: Demonstration of aerosol property profiling by multiwavelength lidar under varying relative humidity conditions, J. Atmos. Ocean. Tech., 26, 1543-1557, 2009.

Veselovskii, I., Dubovik, O., Kolgotin, A., Lapyonok, T., Di Girolamo, P., Summa, D., Whiteman, D. N., Mishchenko, M., Tanré, D.: Application of randomly oriented spheroids for retrieval of dust particle parameters from multi-wavelength lidar measurements, J. Geophys. Res., 115, D21203, doi:10.1029/2010JD014139, 2010.

Weinzierl, B., Petold, A., Esselborn, M., Wirth, M., Rasp, K., Kandler, K., Schütz, L., Koepke, P., Fiebig, M.: Airborne measurements of dust layer properties, particle size distribution and mixing state of Saharan dust during SAMUM 2006, Tellus, 61B, 96117, 2009.

Winker, D. M., Hunt, W. H., and McGill, M. J.: Initial performance assessment of CALIOP, Geophys. Res. Lett., 34, L19803, doi:10.1029/2007GL030135, 2007.
Winker, D. M., Pelon, J., Coakley, J. A., Ackerman, S. A., Charlson, R., Colarco, P. R., Flamant, p., Fu, Q., Hoff, R. M., Kittaka, C., Kubar,. T. L., Le Treut, H., MvCormick, M. p., Megie, G., Poople, L., Powell, K., Trepte, C., Vaughan, M. A., Wielicki, B. A.: The CALIPSO mission: a global 3D view of aerosols and clouds, Bull. Amer. Meteor. Soc., 91, 1211-1229, 2010.

Yoshioka, M., Mahowald, N. M., Conley, A. J., Collins, W. D., Fillmore, D. W., Zender, C. S., and Coleman, D. B.: Impact of desert dust radiative forcing on Sahel precipitation: Relative importance of dust compared to sea surface temperature variations, vegetation changes, and greenhouse gas warming, J. Climate, 20, 1445-1467, doi:10.1175/Jcli4056.1, 2007.

YPEKA, Annual Report for Air Pollution in Athens, Ministry of Environment, Athens, Greece, 79 pp., 2010 (in Greek).

Yu, S., Dennis, R., Roselle, S., Nenes, A., Walker, J., Eder, B., Schere, K., Swall, J., and Robarge, W.: An assessment of the ability of three-dimensional air quality models with current thermodynamic equilibrium models to predict aerosol $\mathrm{NO}_{3}^{-}$, J. Geophys. Res., 110, D07S13, doi:10.1029/2004JD004718, 2005.

Zhang, J., Chameides, W. L., Weber, R., Cass, G., Orsini, D., Edgerton, E. S., Jongejan, P., and Slanina, J.: An evaluation of the thermodynamic equilibrium assumption for fine particulate composition: Nitrate and ammonium during the 1999 Atlanta Supersite Experiment, J. Geophys. Res., 107, 8414, doi:10.1029/2001JD001592, 2003. 